\title{
ADVICE IN JAPANESE RADIO PHONE-IN COUNSELLING
}

\author{
Lidia Tanaka
}

\begin{abstract}
Unlike the short and specific advice of service-encounters, advice in counselling settings is longer and more complex. In these interactions, it is known that advice is initially resisted in all languages. Scholars have tried to explain this phenomenon in terms of 'face loss' (Brown and Levinson 1987; Goldsmith 1992, 1994; Hinkel 1994; Murakami 1994); premature delivery (Heritage and Sefi 1992); the inappropriateness of the advisors (Jefferson and Lee 1992); or discrepancies in the interpretation of a problem (Murakami 1994).

One of the difficulties in counselling or therapeutic settings is that the giving of advice in these interactions is a 'process' that is long and complex. In order to understand advice resistance, it is essential, first and foremost, to identify the characteristics of advice and how it is delivered. The present analysis of Japanese radio phone-in programs focuses on advice in order to identify its formal characteristics and also to try to understand the factors that determine its acceptance or resistance.
\end{abstract}

Keywords: Advice; Radio phone-in; Counselling; Japanese.

\section{Introduction}

A potential loss of face is inherent in the variety of interactions in which advice is sought and offered; these are situations where advice recipients might feel 'less knowledgeable' than advice-givers while advisers may feel rejected if their advice is not accepted, thus both can suffer 'loss of face' (Altman 1990; Brown and Levinson 1987; Goldsmith 1992, 1994; Heritage and Sefi 1992; Hinkel 1994, 1997; Levinson 1992). Another aspect of advice-giving is that advisees tend to show initial resistance to advice even when it has been actively sought (see e.g. Heritage and Sefi 1992; Goldsmith 1999). Advice-giving between friends can also be an FTA as it contains the potential for being interpreted as imposition or criticism by the listener (Goldsmith 1999). While advice is given in all types of interactions, the consequences of losing face are different in each encounter. When talking to friends or family, losing face is not as serious as in public exchanges such as on radio or television. Thus, acceptance of advice by the advisee in institutional exchanges is paramount as it is likely to be seen as indicative of the success of the counselling session, indirectly reflecting the advisers' counselling skills.

Some studies suggest that advice is initially 'resisted' as a face-saving strategy because it implies that the advisee is less competent or capable than the adviser (Goldsmith 1994). Other studies have suggested that advice is resisted because it is 
prematurely given (Heritage and Sefi 1992), in particular, when the adviser does not try to understand the advisee or does not take into consideration the advisee's experience or knowledge. There are other situations in which advice is given indirectly as a 'point of information' to avoid imposition (Culpeper, Crawshaw and Harrison 2008; Leech 1983) or is implied through criticism or reproach (Tanaka, 2014). This last aspect of advice is directly related to the nature of indirect speech acts that allow multiple interpretations (Blum-Kulka 1987; Grice 1978; Kissine 2013; Searle 1975; Terkourafi 2011). Criticism in counselling can, therefore, be interpreted as advice. In particular, when we consider counselling encounters or radio phone-in programs as speech activities, the functions and interpretations of direct (and indirect) speech acts are particular to those speech activities (Levinson 1992).

One of the issues of the advice-giving process in counselling, as opposed, for example, to advice given on an information desk, is that the interaction becomes rather long and complex when the advisee has to be persuaded to accept the advice (DeCapua and Dunham 1993; Gaik 1992; Murakami 1995). In order to understand how advice is given, some studies have carried out detailed analysis of these interactions and problems that occurred within them (Heritage and Sefi 1992; Jefferson and Lee 1992). Other studies have looked at the syntactic characteristics of advice (see e.g. Gaik 1992; Hudson 1990).

Defining advice as a speech act is also quite complex as it can be a directive or a request for an action that will benefit the hearer (Goldsmith 2000; Locher 2006). Because advice is considered to be intrinsically an FTA, it can often be given through indirect speech acts (Brown and Levinson 1987; Searle 1975). In other words, advice can be implied through rhetorical questions, proverbs or suggestions, and this aspect is closely related to politeness (Brown and Levinson 1987) as well as to other factors (Culpeper 2005; Kissine 2013; Tanaka 2014). This aspect of advice-giving is more pronounced in radio or media counselling, in particular, when the advisee does not elaborate what kind of advice she/he is expecting to get. It is very often the case that the advisees' problems are symptomatic of more complex issues and it is throughout the counselling session that these come to the surface. In these cases, advice is accompanied by persuasion or other speech acts. Therefore, advice-giving has to be seen as a 'process', and the reasons for why advisees resist advice have to be investigated with reference to this advice-giving process.

Although some have questioned the universality of advice as an FTA (Hinkel 1994, 1997), in particular in Asian cultures, most other studies show that it is also an FTA and indeed resisted by advisees (Hoshino 2005; Leppänen 1998; Murakami 1994; Shima 1993, Suzuki 2002, 2003, 2007). Existing research on Japanese, for example, has reported that advice is resisted in counselling (Murakami 1994; Suzuki 2007), and researchers have looked at interactional features of advice (Murakami, 1994), the relationship between grammatical features and the relationship between the interlocutors (Shima 1993). They have also categorized the stages of these interactions showing that the paths are rather predictable (Suzuki 2002, 2003, 2007). However, despite interesting results, one of the major problems is that there is no consensus as to what constitutes advice. While some grammatical features are associated with advice giving (e.g. exhortatives, imperatives, conditionals), there are situations in which it is inferred and given indirectly as a 'point of information' to avoid imposition (Leech 1983). In fact, there are many instances in the data when the advice is implied through 
criticism or reproach (Tanaka 2014). Similarly, there is a lack of studies focusing on the reasons for advisee's resistance, with the exception of Murakami (1994).

To increase our understanding of advice in Japanese (and why it is resisted), it is essential to first determine the formal characteristics that define advice. How explicitly is advice given? Is explicit advice more easily accepted than that which is inferred? Or is advice acceptance simply not related to types of advice but rather to other reasons. This study attempts to address these questions by focussing on the advice given in Japanese phone-in programs. Based on the analysis of twenty-seven programs, all instances of advice are identified to distinguish their formal characteristics. This paper shows, firstly, that advice in radio counselling is varied, but mostly given indirectly; and, secondly, that advice has to be considered as part of a 'process' due to the complex nature of problems. Furthermore, this study concludes that advice acceptance seems to be related to timely delivery and to the topic of the problems.

\section{Studies on advice in institutional settings}

Research on advice has mainly looked at medical or therapeutical encounters, radio programs and educational interactions; thus, these have been speech activity studies. Some have looked at advice characteristics, while others have included advisees' reactions, and a third group have taken a cross-cultural approach. This paper is primarily concerned with studies focusing on therapeutic counselling, including radio and television phone-in programs.

\subsection{Reaction to advice}

Many studies on 'institutional' advice in English have reported on advisees' 'resistance', a reaction thought to be caused by the premature delivery of advice and also possibly related to interactional problems (Jefferson and Lee 1992; Heritage and Sefi 1992). Troubles tellers are happier to accept advice from a professional encounter rather than obtaining emotional reciprocity from other advisers such as friends, suggesting that advice giving creates a perceived difference in status (Jefferson and Lee 1992). When troubles tellers talk to non-professional people, the focus is on the telling rather than the advice whereas emotional reciprocity from professional advisers is unwelcome. This discrepancy in the expectations of the teller and the giver is seen in the work of Heritage and Sefi (1992) on nurse visits to new mothers. New mothers' responses to advice are in the form of marked or unmarked acknowledgements, assertions of knowledge and overt rejections. The authors report that marked acknowledgements were rarely found; however, the response to advice initiated by health visitors, in the UK study, was answered by unmarked acknowledgments. More than half of the advice was met by passive or active resistance. In these interactions, advice-giving is often carried out by health visitors who presume that the new mothers lack abilities and also that their efforts to understand what they are specifically lacking in knowledge might be counterproductive. A similar study on Swedish nurses shows that the Swedish patients are more straightforward as their response to advice tends to be either a marked acknowledgement or open rejection. These differences and similarities in the ways in 
which advice is received indicate that even though both are medical encounters, the contexts are quite different and thus the expectations and the interactions are also different. The high rate of rejections in the UK study reflects a mismatch in how mothers and health visitors deal with newborn babies. Health visitors might be over confident in their expertise and take a 'pessimistic' view of the new mothers' capacities. Advice is given even in the absence of a 'problem' making new mothers feel incompetent. Advice in these encounters was felt by advisees to be counterproductive.

It is interesting that the signalling of resistance is very similar in quite different languages: English, Swedish and Japanese. Advisees' reactions in Japanese have been only tangentially analysed, apart from Murakami's studies (1994). She focuses on successful and unsuccessful advice sessions in radio programs where children's problems are discussed. The linguistic and pragmatic features of advisees' resistance to advice are observed in long pauses, lengthening of backchannels, and contrastive conjunctions (kedo, demo, ga 'but', kara 'because'). Murakami notes three types of rejections: (1) rejection of advice which is caused by a discrepancy in the advisers' and the advisees' perceptions of the assessment of the problem, (2) rejection on the basis of the content of the advice and (3) rejection as a result of the unchanged advice (even after the initial resistance). However, she acknowledges that the data used in the study is not sufficient to reach any conclusions and that the fact that the advisee is the mother of the child with a problem presents other dimensions not dealt with in the study.

\subsection{Features of advice}

Research on the features of advice has broadly looked at advice given during medical encounters and television or radio counselling. Leppänen (1998) writes extensively about nurses' visits to patients' houses concluding that most of the advice is designed around the fact that it might be resisted or rejected. Therefore, advice is conveyed through (1) imperative forms or (2) modal verbs of obligation when the nurses know that the patients have an understanding of the issue. On the other hand, they give mitigated forms of advice when they see that patients are not aware of the problems involved. Leppänen's (1998) study includes a comparison with Heritage and Sefi's (1992) study, and shows that the advice given by nurses in Sweden is more straightforward than that of health visitors in the UK. One of the reasons, Leppänen suggests, is that Swedish nurses give the advice only after they see a medical problem as opposed to the UK health visitors who provide advice without assessing the degree of knowledge that new mothers possess. One of the differences in these two settings is that the Swedish nurses give advice only where they have determined that it is needed, whereas the UK nurses take a 'pessimistic' view as the basis of their interactions.

How advice is given in radio programs in terms of grammatical and discourse characteristics has been studied by Gaik (1992) and Hudson (1990). Gaik (1992) makes a distinction between therapeutical and counselling activity. He argues that the use of irrealis, by the counsellors as a strategy to 'find unique sources of the caller's anxiety and to promote introspection' (Gaik 1992: 277) is crucial in therapeutic interactions. That is, the use of irrealis is a very effective tool for an advisor trying to help a caller find the reasons for his/her anxiety. However, in counselling, the use of irrealis is counterproductive and the normative statement is more effective. Hudson (1990), on the 
other hand, reports that directives and 'interpersonal markers' are used to soften the advice that is given. A critical difference is that Hudson's radio programs concern gardening, where the advice-giver has more latitude to offer advice without it being an FTA, whereas in Gaik's study the problems are of a personal nature. The topic of the 'problems' undoubtedly also influences the type of advice and its reception. A less personal 'problem' such as one concerning gardening might be less face-threatening than child rearing issues, for example.

Hutchby (1995) and DeCapua and Dunham (1993) have focused on the influence of the overhearing audience in a radio broadcast. The delivery of advice creates 'tension' as it has to be directed not only towards the caller but also to the overhearing audience (Hutchby 1995). Hosts, who are not experts, pose proxy questions which, without offending the experts, facilitate the dispelling of this tension; they enable the counsellors to give an auxiliary response containing additional information that also benefits the audience (Hutchby 1995). A similar study shows that the advice in radio programs is directed at both the advice seeker and the wider audience. Callers tend not to seek specific advice and therefore hosts need to resort to considerable probing in order to obtain a comprehensible picture of the situation (DeCapua and Dunham 1993). This aspect reflects the difficulties that experts face in trying to give advice.

The few existing studies on Japanese advice and its characteristics have restricted themselves to: The structure of radio programs (Nakamura and Kashida 2004; Suzuki 2002, 2003, 2007); the politeness aspect (Hoshino 2005; Shima 1993); and the nature of successful/unsuccessful sessions (Murakami 1994). Nakamura and Kashida (2004) describe the 'institutional' character of help-lines and the a priori nature of the sequence of actions. They also show how caller and call-taker maintain the asymmetry in the interaction which entitles the call-taker to claim expert knowledge (membership categorization device (MCD) coined by Sacks 1986). Similarly, call-takers use a variety of strategies which can momentarily change the asymmetrical relationship and may result in unexpected interactional problems; however, these are soon overcome by the establishment of another MCD (Nakamura and Kashida 2004). This study sheds light on how the process of advice giving is structured and demonstrates that experts have to carefully select their next move in order to keep the counselling exchange running.

Suzuki's $(2002,2003,2007)$ work on advice expands into other interactions (at a library's reference desk and textbook dialogues); however, here we will only concentrate on results relevant to this study. She identifies 4 structural units or wadan in her data from radio and TV broadcast psychological and medical counselling. Within those units, she first identifies speech acts, based on Szatrowski's (1994) model, and looks into their grammatical features. In medical counselling, the wadan where the advice takes place, contains expressions with the endings hooga ii to omoimasu ' $\sim$ you'd better do X', and temite kudasai 'Please try doing X'. In contrast, the patterns in the psychological counselling are indirect with constructions such as yattemitewa ikaga deshooka 'How about trying to do x?' and the use of mollifiers such as chotto or sukoshi 'a little'. The analysis in Suzuki's studies shows that there are four different patterns in advice-giving interactions where the shorter pattern indicates a smooth delivery of the advice. However, the discussion in her 2003 study lacks depth as she does not explore the reasons for the differences in advice giving, aside from mentioning that psychological counselling needs more careful management, and that this results in the advisors using more indirect expressions. There are many other factors that could have 
affected the interaction such as the topic, the advisees' ages, their relationships and gender that are not taken into consideration.

Hoshino (2005), who studied advisers' strategies from the viewpoint of politeness, shows that advisers use positive politeness strategies oriented to themselves or to the advisees. The former includes references to the advisers' rich experience and expertise showing that they are the people best placed to give the advice. The latter strategies are used to facilitate the advice delivery- as seen in the advisor's praise of the advisees or acknowledgement of their plight, and are used to soften harsh advice or comments. Hoshino's detailed analysis is incisive and shows how strategic the advisers' comments are; however, there are also cases of positive politeness which act not to project friendliness, but the presence of a clear distinction or power relationship, an aspect omitted in Hoshino's study.

While the relationship between interlocutors is an important aspect of communication, only Shima's (1993) work, based on data from movie and TV drama scripts, looks into the gender and age of interlocutors as well as their relationships. Most of the advice in her data is given in the conditional forms tara, ba suggesting that these might be the default grammatical forms for advice. The advice is mostly given by lower to higher status persons; and, most of the users of these advice forms are children or women. The existence of gender-related differences seems to be indicated by women using the conditional forms accompanied by the adjective $i i$ and men using the bare forms. More importantly, when men give advice, they use the imperative forms. Through the inclusion of several factors in the analysis of the interactions, Shima's study furthers our understanding of how advice is given; however, there is a limit to the conclusions that we can draw from data on the basis of movies and TV drama scripts as there are questions regarding how well these reflect communication in authentic interactions. A further problem with Shima's use of this data is the lack of clarity regarding whether the advice is actively sought or given without having been requested.

Murakami's (1994) work, mentioned in the previous section, includes an analysis of the type of advice given. She writes that in successful sessions, the counsellor takes the lead and the advice is in the affirmative conditional. By contrast, advice in unsuccessful sessions is expressed in negative expressions known to restrict the scope of the value judgment. The advice is delivered with a number of characteristics that can be taken as 'mollifiers' or softeners, but also as signs of insecurity (Murakami 1994). While Murakami's study is very interesting, the fact that the programs which make up her data set deal with similar topics (a feature acknowledged by the author as a weakness of the research) and also that the caller is always the child's mother are limitations, as mentioned previously.

\subsection{Cross-cultural studies}

DeCapua and Dunham's (1993) study, conducted using a discourse completion questionnaire aimed at detecting any differences in the advice-giving styles of native English speakers, proficient non-native speakers and ESL learners, yielded unexpected results. The proficient non-native speakers' advice most closely resembled that given by the ESL students, suggesting that pragmatic norms are culturally different. When advice was given in the imperative form, American native speakers of English used mollifiers 
such as maybe, just while non-native speakers used no mollifiers. This study suggests that there might be some cultural differences in how advice is perceived; however, research on Japanese advice (and in some other languages) indicates that advisees from other language groups are equally resistant to advice as English speakers.

Another comparative study, of American and Japanese advice radio programs, describes cultural differences in what advice seekers are looking for and how advisers give their advice (Abe, 2006). Contrasting differences were observed in what advisees expect and what advisers deliver. Japanese advisees do not mind if there is no resolution and are quite content with the fact that advisers have listened to them while American advice seekers are after practical and concrete advice. Japanese advisers take various positions- ranging from authority figures to equals - as opposed to the American advisors who take only one stance and deliver advice from a position of authority. These observations are very interesting, not only from the viewpoint of cultural differences but also from the perspective of the advisees' needs. It might be the case that Japanese advisees are seeking a therapeutic type of interaction when they use these services.

\section{The radio phone-in program}

Radio phone-in interactions, and other institutional exchanges, are quite different to casual conversation on various levels (Heritage and Drew 1992; Have ten 1993, 1999). Firstly, the relationship between the interlocutors where counsellors (and hosts) have a higher status than callers is unequal. This difference in status is the result of not only the counsellors' and hosts' inherent rights to conduct the program but also because of their standing in society. Counsellors in Japanese radio phone-in programs are famous and acknowledged professionals in their own fields in contrast to the anonymous callers from the public. The hosts' rights allow them to commence and conclude the program, and both hosts and counsellors can ask questions. Although callers also ask questions, these are limited to the topic. Secondly, these interactions are goal oriented and constrained by time limits unlike daily conversations. Thirdly, there is an audience that, despite not actively participating, plays an important role as many of the hosts ask questions or give advice with this silent participant in mind.

The data used in the present study consists of twenty-seven radio phone-in programs recorded from 2002 through 2009 known as Terefon Jinsei Soodan. This program has been broadcast in Japan by Nippon Hoosoo, a private radio company, for more than thirty years and it is still being aired, an indication of its popularity and of the fact that people not only enjoy listening but also resort to it for advice. The 20 minute daily program is broadcast nation-wide and there are three active participants: The host, the counsellor and the caller. Counsellors are professional people such as lawyers, psychologists and doctors while callers are anonymous people from the public. Callers sometimes call on behalf of a relative on a wide variety of problems such as: Financial, relational, marital, parental and mental health. These 'troubles' can be quite complex. 


\section{Advice as a process}

This section shows how the process of giving advice occurs in the programs once the counsellor is introduced. Defining advice, as mentioned earlier, is complex because of the range of encounters that it spans; radio counselling is a longer and more intricate interaction than, for example, that which occurs at a reference desk. A primary difficulty in radio counselling is that the problems are complex and sometimes only symptoms of the real cause. The second obstacle is that advisers do not always specifically advise callers using conventional advice forms, but use indirect speech acts to soften the advice (Searle 1975; Terkourafi 2011) or for other reasons (Culpeper 2011; Geis 1995; Kissine 2013; Tanaka 2014). A third complicating factor is that advice in radio counselling is not given in a single turn but is often part of a 'package'.

Advice in radio counselling has to be seen as a process because it is often intrinsically embedded in the expert's interpretation of the problem, efforts at persuasion or explanation. In other words, advice, explanation and persuasion are all interconnected and inseparable in the data. Legal counselling, in particular, is complex because of the amount of information and legalese, as seen in the following examples of legal advice. In excerpts (1)-(3) the caller has phoned in about her younger brother's financial problems. In order to facilitate the reading and explanation of the data, this example is divided into three sections.

In the first section (lines 1-12), the counsellor persuades the caller to become better informed about her brother's debts (lines 1-4) and advises her to summarize this information. This advice is given as an opinion that ends with omoundesune 'I think'. The caller sends the affirmative answer hai; however, this does not contain an agreement in its pragmatic function as it is given with a lengthened vowel which indicates some hesitation (line 5). This is followed by an explanation (lines 5-10). The counsellor points out that once the caller has established the whole picture of her brother's debt, he himself should look at it and think seriously about what actions to take. Then, the second piece of advice is given in lines 10-13. The host uses a prohibition kangaete itadakanakucha ikenai '(you/we) need him to think seriously' which implies that it is something the caller (the sister) has to realize and is accompanied by the SFP (sentence final particle) $n e$ which acts as a hedge. The third piece of advice is immediate and warns that the caller's brother has to reappraise his lifestyle, and uses an incomplete suggestion in the conditional form minaoshite itadakanaito 'if he does not reappraise (his lifestyle)'. It is common in Japanese to leave sentences syntactically unfinished (Hayashi 2003; Tanaka 2004, 2006). We can speculate that by not finishing the advice, the caller (and the audience) can think of the consequences if the suggestion is not followed. In a way, this advice is less forceful because by not imposing on the advisee it leaves it to the caller to judge the consequences of inaction. Note that after each 'unit' there is a backchannel from the caller (lines 12 and 13) indicating that she is listening attentively. 
(1) $(30.09 .05)$

\begin{tabular}{|c|c|c|c|c|c|c|c|c|c|}
\hline & $\begin{array}{l}\text { hai. } \\
\text { yes }\end{array}$ & $\begin{array}{l}\text { desukara } \\
\text { therefore }\end{array}$ & $\begin{array}{l}\text { chotto } \\
\text { little }\end{array}$ & $\begin{array}{l}\text { desu } \\
\text { COP }\end{array}$ & $\begin{array}{l}n e, \\
\text { SFP }\end{array}$ & $\begin{array}{l}\text { otoot } \\
\text { youn }\end{array}$ & $\begin{array}{l}\operatorname{san}^{2} \\
\text { brother }\end{array}$ & $\begin{array}{l}\text { no: } \\
\text { of }\end{array}$ & \\
\hline 2 & $\begin{array}{l}\text { sono: } \\
\text { that }\end{array}$ & $\begin{array}{l}\text { shakkin } \\
\text { debt }\end{array}$ & $\begin{array}{l}\text { no } \\
\text { of }\end{array}$ & $\begin{array}{l}\text { zenyoo } \\
\text { whole }\end{array}$ & to & $\begin{array}{l}i u \\
\text { say }\end{array}$ & $\begin{array}{l}\text { no } \\
\text { COM }\end{array}$ & $\begin{array}{l}k a, \\
\mathrm{Q}\end{array}$ & $\begin{array}{l}\text { (H: } \boldsymbol{n}, \\
\mathrm{mhm}\end{array}$ \\
\hline & $\begin{array}{r}\text { Ca: } \boldsymbol{h} \\
\text { yes }\end{array}$ & $\begin{array}{l}\text { to } \\
\mathrm{Qt}\end{array}$ & $\begin{array}{l}i u \\
\text { say }\end{array}$ & $\begin{array}{l}\text { no } \\
\text { COM }\end{array}$ & $\begin{array}{l}o \\
\text { of }\end{array}$ & $\begin{array}{l}\text { desu } \\
\text { COP }\end{array}$ & $\begin{array}{l}n e: \text {, } \\
\text { SFP }\end{array}$ & $\begin{array}{l}\text { moo: } \\
\text { more }\end{array}$ & \\
\hline
\end{tabular}

$\begin{array}{llllll}4 & \text { sukoshi: } & \text { yoku } & \text { seirisarete, kikarenaitoikenai } & \text { to } & \text { omou } \\ \text { little } & \text { well arrange-CONJ hear-HON-must } & \text { Qt } & \text { think COM }\end{array}$

5 desu ne: (ha:: i) sorede:naiyoo o tsukandara desu ne:,

COP SFP yes then contentof catch-COND COP SFP

6 (hai) kore $o$ doo shiyoo $\quad k a$ tte, yappari yes that of how do-HORT Q Qt after-all

7 kore wa shujinkoo wa otootosan na $n$ this TOP main-characterTOP young-brother COP COM

8 desu yo ne. (H: hai, Ca: hai) dakara otootosan ga

COP SFP SFP yes yes thus young-brother $\mathrm{S}$

$\begin{array}{llllll}\text { jibunde } & \text { sono: } & \text { gojibun no } & \text { shyuunyuu } & \text { to } & \text { ryoohoo } \\ \text { himself } & \text { that himself-HON of } & \text { income } & \text { and both }\end{array}$

10 kara mite hontooni muzukashii. (hai) soshitara from see really difficult yes then

11 dooiu fuuni $\begin{array}{lllllll}\text { shitara } & \text { ii } & n & \text { daroo } & k a & \text { to, } \\ \text { what way } & \text { do-COND } & \text { good } & \text { COM } & \text { COP } & \text { Q } & \text { Qt }\end{array}$

$12 \frac{\text { (hai) }}{\text { yes }} \quad \begin{array}{lllll}\text { iu } & \text { koto } & \text { o } & \text { shinkenni } & \text { kangaete } \\ \text { say } & \text { COM } & \text { of } & \text { seriously } & \text { think }\end{array}$

13 itadakanakuchaikenaidesu $\begin{array}{llllll}\text { yo } & \text { ne? } & \text { (hai) } & \text { ano: } & \text { jibun } \\ \text { receive-must } & \text { COP } & \text { SFP } & \text { SFP } & \text { yes } & \text { uhm himself }\end{array}$

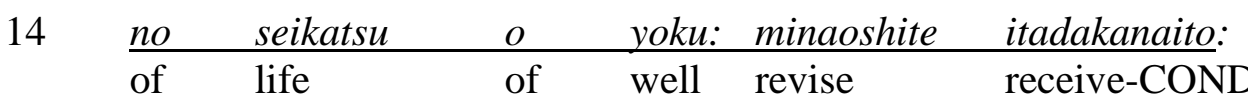

\footnotetext{
${ }^{1}$ Co: counsellor, Ca: Caller, H: Host

2 The closest gloss in this context of the word otootosan is 'your younger brother'; however, for space-saving-sake it will be glossed only as young brother.
} 


(hai) ato: sono: kono sai:mu no seiriosurunonishitemo
yes and that this debt of sort-for-even

'Co; Yes, therefore, how should I put it, the whole of the debt (H: $\mathbf{m h m}, \mathbf{C a}$; yeah) you need to ask him and put it in order (yes) and, when you understand the content (yes) what you do with it, well, after all the protagonist is your brother, isn't he? (H:yes, Ca: yes) that is why, your brother [has to see] that the [situation] is difficult from his salary and his debt (yes) then, you must make him think seriously about what to do, musn't you? (yes) well, he will have to reappraise his lifestyle, otherwise (yes) and, uhm, to sort his debts'

In (2), the counsellor gives a rather long explanation with more advice (lines 16-33). He explains that the brother needs to re-evaluate his finances once they have an understanding of all the debts he has incurred and of his income after payments. The next piece of advice is an assertion of opinion that appears in a compound sentence. The first part is in the conditional form sono ato haittekuru shuunyuu dakede seikatsu dekiru yooni shiteokanaito 'if he cannot do that (survive with only his income) (line 18-19) and the second part says that it would be impossible sorewa fukanoo dato omoimasune for him to survive (financially). The counsellor continues with more advice, saying that if that is not possible sorega dekinai toiu koto de aru naraba, the caller's brother could 'dispose of part of (his) real estate' fudoosan o ichibu shobun sarete and motto chiisai tokoro ni utsurarerunari 'do things like move to a smaller place'. The host, who is not actively participating at this stage, seems to agree with the explanation and sends a backchannel. The counsellor suggests that by doing those actions (selling and moving) the brother should be able to cover his living expenses soshite sorede sono seikatsuhi o hotenshite iku yoona katachi o kangaeru to (line 21-26). The next piece of advice starts in line 26 after the word tada 'but', which sounds like a caveat that warns of the consequences if the brother does not live within his means yahari shyuunyuu no han' $i$ de seikatsu o suru tte iu koto o atama ni irete okanaito. Again, this sentence is grammatically incomplete but it makes clear that there will be consequences. It is also closely linked to the next piece of advice which is given as an instruction that suggests what the caller should tell her brother. The counsellor says that the brother will be facing a reduction in his salary when he starts receiving a pension and that, therefore, he (the brother) needs to reappraise his situation. Notice that in this section too backchannels are given after clauses (lines 20, 23, 26, 30, 31, 33) indicating that the caller is listening attentively. It is also noteworthy that even though all the advice appears with clear associated syntactic features, the caller does not show any resistance.

(2) (30.09.05)

\begin{tabular}{|c|c|c|c|c|c|}
\hline $\begin{array}{l}\text { ato: } \\
\text { and }\end{array}$ & $\begin{array}{l}\text { sono: } \\
\text { that }\end{array}$ & $\begin{array}{l}\text { kono } \\
\text { this }\end{array}$ & $\begin{array}{l}\text { sai:mu no } \\
\text { debt of }\end{array}$ & $\begin{array}{l}\text { seiriosurunonishitem } \\
\text { sort-for-even }\end{array}$ & \\
\hline $\begin{array}{l}\text { desu } \\
\text { COP }\end{array}$ & $\begin{array}{l}n e \\
\text { SFP }\end{array}$ & $\begin{array}{l}\text { (hai) } \\
\text { yes }\end{array}$ & $\begin{array}{l}\text { ichibu } o \\
\text { partly of }\end{array}$ & $\begin{array}{ll}\text { katto } & \text { shitemorau } \\
\text { cut } & \text { receivelike }\end{array}$ & $\begin{array}{l}\text { toka ironna } \\
\text { various things }\end{array}$ \\
\hline
\end{tabular}


17 koto o surunishite mo, (hai) sono ato haittekuru

$\mathrm{COM}$ of do-even too yes that later come-in

18 \begin{tabular}{lllll} 
shuипуии & dakede seikatsu & dekiruyoonishiteokanaito, & sore & wa, \\
\hline income & only life & be-able-do-COND & that & TOP
\end{tabular}

$19 \begin{array}{lllllll}\text { fukanoo } & d a & \text { to } & \text { omou } & n & \text { desu } & \text { ne. } \\ \text { impossible } & \text { COP } & \text { Qt } & \text { think } & \text { COM } & \text { COP } & \text { SFP }\end{array}$

20 (hai) ato no seikatsusurunoni.

yes after of live-do-for

21 (H: soo. da yo ne.) de, sore ga, dekinai yes COP SFP SFP and that S do-COND

22 \begin{tabular}{llllll} 
to & iu $\quad$ koto & ni & narareru & $n$ & dattaraba, \\
\hline Qt & say COM & in & become & COM & be-COND
\end{tabular}

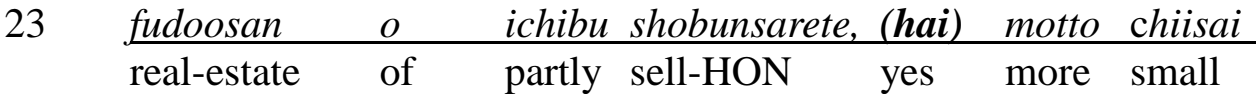

24 tokoro ni utsurarerunari, (H: soo.soo) nannarishite, soshite, place in move-HON-like yes.yes do-like and

25 sorede sono seikatsuhi o hotenshite iku yoo-na

then that living-expenses of compensate go like

26 \begin{tabular}{llllll} 
katachio, & kangaeru & to. & (hai) tada & yahari shunyuu \\
\hline form of think & Qt yes only still income
\end{tabular}

$27 \begin{array}{lllllll}\text { no } & \text { han'i de } & \text { seikatsusuru } & \text { tte } & \text { iu } & \text { koto } & \text { o } \\ \text { of } & \text { within of } & \text { live } & \text { Qt } & \text { say } & \text { COM of }\end{array}$

28 shikkari atama ni ireteitadakanaito, (hai) korekara well head in input-COND yes afterwards

29 ano: dandan shuипуии wa herarerushi, ma nenkin: well ONMT income TOP reduce well pension

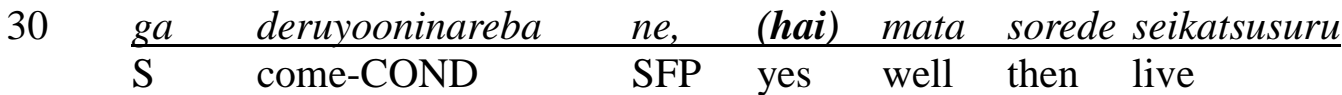

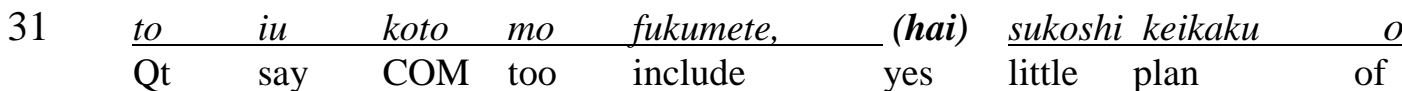




$\begin{array}{llcl}\text { yoku } & \text { tateteitadaku yoona } & \text { katachide, } & \text { (H:un) } \\ \text { well poo } & \text { put-receive-HON-once } & \text { form and } & \text { uhm }\end{array}$

\begin{tabular}{lll} 
minaoshiteminasai & to, & (hai) \\
\hline re-think-IMP & Qt & yes
\end{tabular}

'Co: Then even to put in order his debts, you see (yes), even if he can reduce them partially (yes) he will need to be able to survive on his salary, otherwise it will be impossible, you see (yes) to be able to survive (H: that's right) and if he cannot do that, he will have to do things like selling part of his real estate and (yes) move somewhere smaller (H: yes, yes) and then try to supplement it with the sale (yes) only, what, unless he really understands that he has to live within his means (yes) his income will decrease, well when he starts getting his pension (yes) he will have to survive on that (yes) so it will have to be planned really well $(\mathbf{H}: \mathbf{m h m})$ so the situation needs to be reassessed (yes) and for that'

In the subsequent lines (34-45) a number of pieces of direct advice are offered: The caller is requested to tell her brother to see a lawyer or professional (line 34); to get all the information possible from this expert (line 35-6); to select the best solution from those choices (lines 36-8); and to accompany her brother to see the lawyer in order to get the full picture herself (lines 39-42). The first piece of advice is adobaisu shiteagete 'advise him' given in a shortened expression of the verb in $\sim$ te form, used in requests that are usually accompanied by verbs such as kudasai or kureru. It requests that the caller advise her brother to go to an expert (a lawyer) senmonka no tokoroni soodanni itte to establish 'which is the best solution' dooiu hoohoo ga ichiban ii, and make him choose one. He also suggests that the caller should accompany her brother when he sees the lawyer (see lines 40-41). For this advice, the counsellor uses a shortened request form isshoni irashite 'go together' and tells her the positive results if they follow his suggestion. After this long section, the counsellor wraps up his last piece of advice in line 44, where he uses the expression gosoodan ni nattemitara ikaga deshooka 'how about consulting someone'. The caller shows her cooperative attitude by sending backchannels in places where they are expected to occur (after clauses or SFPs). Again, as in the previous sections, the caller shows her attention but does not react negatively.

(3) (30.09.05)

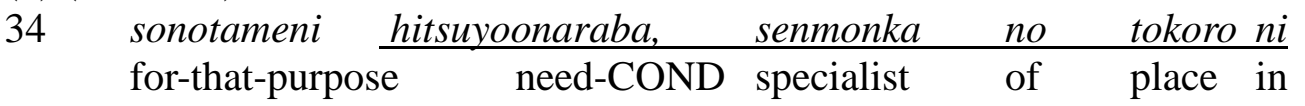

$\begin{array}{llllll}\text { soodanniitte, } & \text { (hai) } & \text { dooiu hoohoo } & \text { ga } & \text { ichibanii } & \text { noka, } \\ \text { advice-go } & \text { yes } & \text { which way } & \text { S } & \text { best } & \text { like }\end{array}$

$\begin{array}{llllll}\text { (hai) } & \text { yoku } & \text { kikidashite, } & \text { soshite soreni } & \text { shitagatte, } & \text { jibun } \\ \text { yes } & \text { well } & \text { get-information } & \text { and that follow } & \text { oneself }\end{array}$




\begin{tabular}{|c|c|c|c|c|c|c|c|}
\hline$a$ & dore & $O$ & yattara & $i i$ & noka & $o$ & sentakushitara \\
\hline 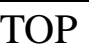 & & of & do-COND & good & like & of & select-CON \\
\hline
\end{tabular}

\begin{tabular}{llllll} 
iinjanai, & to & iu & katachide, & (hai) & adobaishi..su shiteagete, \\
\hline good & Qt & say & form and & yes & advice do-give-CONJ
\end{tabular}

$\begin{array}{lllllll}\text { (hai) baainiyoreba } & \text { sono } & n: & \text {..sono hooritsusoodan } & \text { nari, } \\ \text { yes } & \text { depending } & \text { that } & \mathrm{mhm} & \text { that legal-counselling } & \text { like }\end{array}$

\begin{tabular}{lllllll} 
nannarini & irassharu & tokini & desu & ne, & (hai) & isshooni \\
\hline like & go-HON & when & COP & SFP & yes & together
\end{tabular}

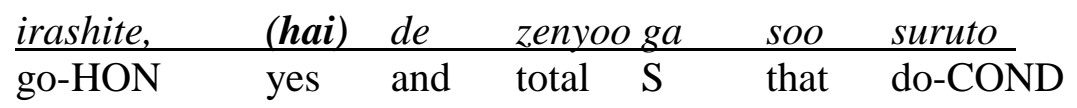

\begin{tabular}{lllll} 
wakaruto & omoimasu & kara, & (hai) & sono nakade, \\
\hline understand-COND & think & thus yes that within
\end{tabular}

$\begin{array}{lllllll}\text { oneesan } & \text { toshite, } & \text { (hai) } & \text { tedasuke } & \text { dekiru koto ga } & \text { arunoka } \\ \text { sister } & \text { as do } & \text { yes help do-POT COM } & \text { be-or }\end{array}$

\begin{tabular}{lllllll} 
nainoka, & (hai) & soo & iu & o & koto & fukumete, \\
\hline be-NEG-or & yes & that & say & thing & of & include
\end{tabular}

$\begin{array}{lll}\text { gosoodanninattemitara } & \text { ikagadeshoo } & \mathrm{ka} . \\ \text { consult-HON-COND } & \text { how-about } & \mathrm{Q}\end{array}$

'Co: For that purpose, if it is needed, you should go to consult with a specialist (yes) and ask what is the best way (yes) and according to that, [he] can choose what is best for him (yes) you can advise him [to do that] and depending on the situation, when he goes to see uhm a legal counsellor (yes) or a lawyer (yes) you go with him [he] then you will understand the whole picture (yes) and then, as an older sister (yes) how about asking if there is any way in which you can help'.

From this excerpt, we can see that advice-giving is a 'process' where the counsellor uses suggestions, opinions, requests that could be embedded within the explanation, the attempts at persuasion, or the problem's interpretation. The counsellor's approach to this process generally reflects the complexity of the problem in that there is no single solution or simple advice to the caller's predicament and very often there are many sequential steps that the advisee needs to take, particularly for legal problems, as in the case above. The counsellor is very clear as to what steps the caller should take and advises callers accordingly. The advice-giving process is made up of various pieces of advice at different points of the interaction. The advice is presented as an assertion of opinion (lines 4-5, 17-19, 39-42), as prohibition (lines 10-13, 13-14), as suggestion (lines 21-24), as requests (lines 34-35, 35-36, 37-38) and as instructions (lines 29-33) 
interspersed with explanation. The advice process sets out a sequence of actions that the caller has to take to, hopefully, obtain a solution to the problems.

Prosodic features and other conversational cues were looked at in the advisees' responses. Immediate answers (or preferred answers) with wakarimashita or thanks were judged to be acceptance of advice. On the other hand, lengthened answers and pauses were seen as resistance. Open rejection sometimes included interruptions and challenges to the counsellor.

Let us look at the advisee's first reaction. In line 5, the advisee's reaction hai, which despite being used as an affirmative answer, is said with a lengthened vowel that demonstrates her reluctance to accept the first piece of advice. However, this is followed by tokens used as backchannels to indicate the advisee's cooperation; a characteristic of Japanese communication (Horiguchi 1997; Tanaka 2004). They might not necessarily mean that she accepts the advice, but there are no signs of resistance (except for the first token) or open rejection. This might be because of the nature of the problem as it does not involve criticism or judgement of the advisee's capacity but, rather, deals with concrete legal actions that are not directly related to the caller's behaviour.

\section{Characteristics of advice}

As seen in the section above, advice is given through requests, orders, suggestions and the like. It is known that speakers can accomplish different social acts through the use of indirect speech acts. As opposed to direct speech acts, these have been associated with politeness, although there are also other reasons at play (Blum-Kulka 1987; Geis 1995; Searle 1975; Terkourafi 2011). Advice can be given in various forms and degrees of imposition such as through suggestions like 'Why don't you see your doctor?' or as commands 'See your doctor immediately' to someone who, for example, has a health problem. While the content of what the speaker wants the listener to do is the same- that the listener goes to a doctor- the way in which it is expressed determines the degree of forcefulness and imposition.

The focus of this study is an analysis of the role played by the manner in which advice is given when attempting to persuade someone to do something. While all speech acts that involve the enforcement of the speaker/adviser's wish for the listener/advisee to do (or not to do) something are intrinsically FTAs (Brown and Levinson, 1987), some are stronger than others and they vary in degree of coercion. Thus, commands are more forceful than requests as the latter are mitigated and have less imposition; suggestions, on the other hand, are phrased in a way that the advice is general and can be applied to anyone in the same situation. For example, the same advice for the patient mentioned earlier can be phrased as 'If one has x symptoms, seeing a doctor is a good idea'. If the advice is given as an over-generalization (Brown and Levinson 1987), or as a suggestion, the advisee has the choice of ignoring it, and therefore we might expect less resistance.

Table 1 and Figure 1 below show the types of advice most frequently used in the data arranged in order of degree of directness, including frequency and location within the stages of the advice-giving process, as well as their reception. It is interesting to see that the most frequent forms of advice are given as opinions (72), requests (34), positive suggestions and prohibitions ( $24 \& 19)$. Direct commands tend to be given at the start of 
the advice-giving phase, while most of the requests are given in the final stages. Reactions of advisees are less clear except for acceptance or open resistance. In the majority of the cases, advice is accompanied by further explanation, so it is uncertain whether the advisees' responses are simple backchannels, acknowledgement or acceptance.

Table 1:Advice types according to degree of directness

\begin{tabular}{|c|c|c|c|c|c|c|c|c|c|}
\hline \multirow[b]{2}{*}{ Advice } & \multirow{2}{*}{\multicolumn{2}{|c|}{ Expressions in/with }} & \multirow{3}{*}{$\begin{array}{l}\text { Total } \\
\text { Raw }\end{array}$} & & \multirow[b]{2}{*}{ Mid } & \multirow[b]{2}{*}{ End } & \multicolumn{3}{|c|}{ Reactions } \\
\hline & & & & \multirow{2}{*}{$\frac{\text { Start }}{\%}$} & & & \multicolumn{3}{|c|}{\begin{tabular}{|l|l|l|} 
Yes & $*$ & $\mathrm{No}$
\end{tabular}} \\
\hline & & & & & & & & & \\
\hline Direct commands & \multicolumn{2}{|l|}{ Imperative form } & 11 & $\underline{63}$ & 9.1 & 27 & 9.1 & 64 & 27 \\
\hline Prohibition & \multicolumn{2}{|l|}{$\sim$ dame, ikenai } & 19 & 16 & $\underline{47}$ & 37 & 16 & 68 & 16 \\
\hline \multirow{3}{*}{ Requests } & hoshii, kurenai & 11 & & 18 & 18 & $\underline{64}$ & 18 & 82 & 0 \\
\hline & ｋudasai & 18 & 34 & 11 & 33 & $\overline{50}$ & 33 & 56 & 1 \\
\hline & $\sim t e$ & 5 & & & & & & & \\
\hline Positive suggestions & \multicolumn{2}{|l|}{$\sim i i$} & 24 & 25 & 17 & 58 & 25 & 67 & 8.3 \\
\hline Suggestions & \multicolumn{2}{|l|}{$\sim$ tara,$\sim b a$} & 29 & 24 & 14 & $\underline{72}$ & 31 & 69 & 10 \\
\hline Asking opinions & \multicolumn{2}{|l|}{ rising intonation } & 11 & 0 & 36 & $\underline{64}$ & 36 & 55 & 9.1 \\
\hline Assertion of opinion & \multicolumn{2}{|l|}{ Declaratives } & 72 & 35 & 32 & $\overline{33}$ & 15 & 64 & 22 \\
\hline Assertion of instructions & \multicolumn{2}{|l|}{ Declaratives } & 15 & 6.7 & 40 & 53 & 33 & 33 & 33 \\
\hline
\end{tabular}

Raw $=$ Raw numbers, Yes $=$ Acceptance, $*=$ backchannels, No= Resistance, rejection

Figure 1 Advice types according to degree of directness

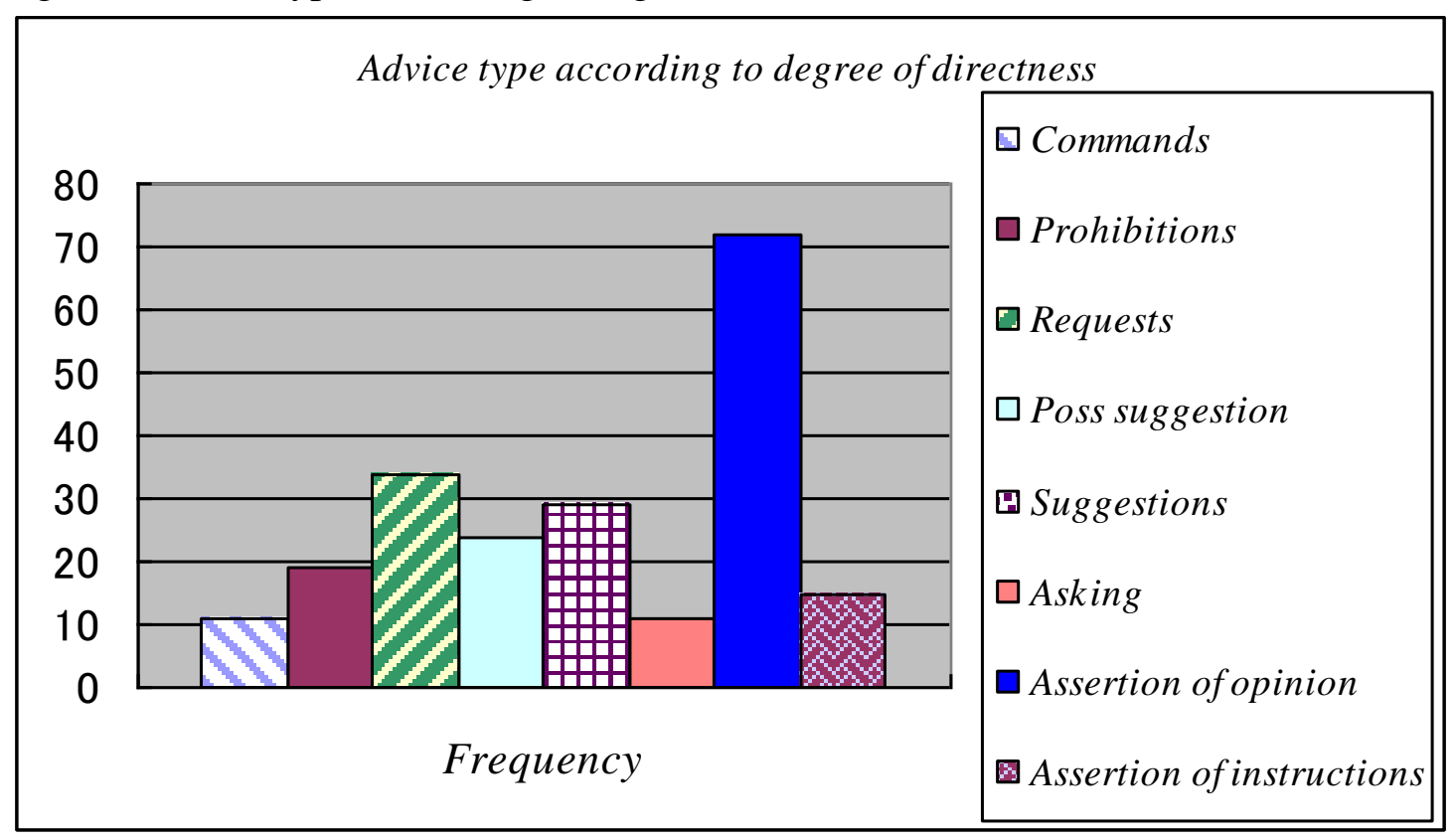

In the following sections we will look in detail at the formal characteristics of advice according to their degree of directness. 


\subsection{Direct commands}

There are two imperative forms in Japanese that are realized in the inflections of verbs and, as seen below, only those associated with a softer stance are found in the present data.

\begin{tabular}{l|ll|ll} 
& \multicolumn{2}{|c|}{ Imperative I } & \multicolumn{2}{c}{ Imperative II } \\
\hline to do & affirmative & negative & affirmative & negative \\
\hline Suru & shiro & suruna & shinasai & shinaide
\end{tabular}

Type I has a strong and authoritative stance, usually associated with male language. This form is used in contexts such as sports training or when the interlocutors know each other very well. Type II is commonly used by mothers when educating their children and in other educational situations. While type I is too rough in an 'institutional' setting, except when used strategically, the second type of imperative is widely used, as we can see below.

In (4), the caller is clearly an unhappy woman, but it is difficult to understand the reasons why. Even after much probing a clear reason for her unhappiness still fails to emerge. In this excerpt the counsellor says that he, incidentally, has experience of working with physically and psychologically troubled people and advises her, on this basis, to seek voluntary work. He even uses the loan word adobaisu o suruno 'I advise you'. He says that she could find a purpose in life by helping other people who are in a worse situation than her. He uses the imperative form sagashitegorannnasai 'try to look for' when suggesting that she look for these kinds of jobs (line 7). He also adds that she should take these actions slowly jojoni yatte gorannnasai (line 10) and that she should go to places like hospitals or community centres to get information about volunteering sooiu toko itte gorannasai (line 13). We can see that the counsellor is trying to persuade the caller with the constant use of the SFP ne which asks for the listener's participation and agreement, to which the caller sends backchannels (lines 7, 12 \& 14). The advisee's reaction is seen in her backchannel hai in lines 8, 13 and 14; however, as mentioned earlier, it is difficult to know whether these responses are used as simple backchannels (Horiguchi, 1997) or whether she is accepting the advice.

(4) (24.02.05)

\begin{tabular}{|c|c|c|c|c|c|c|c|}
\hline $\begin{array}{c}1 \mathrm{Ca}:{ }_{\mathrm{I}} \text { boku } \\
\mathrm{c}\end{array}$ & $\begin{array}{l}w a \\
\text { TOP }\end{array}$ & $\begin{array}{l}\text { tamatama } \\
\text { coincidence }\end{array}$ & $\begin{array}{l}\text { sou } \\
\text { that }\end{array}$ & $\begin{array}{l}i u \\
\text { say }\end{array}$ & & $\begin{array}{l}O \\
\text { do }\end{array}$ & $\begin{array}{l}\text { shiteru } \\
\text { DO }\end{array}$ \\
\hline $\begin{array}{l}\text { mon } \\
\text { COM }\end{array}$ & $\begin{array}{l}\text { dakara } \\
\text { thus }\end{array}$ & $\begin{array}{l}\text { anata } \\
\text { you }\end{array}$ & $\begin{array}{l}n i \\
\text { to }\end{array}$ & $\begin{array}{l}\text { adobaisu } \\
\text { advice }\end{array}$ & $\begin{array}{l}o \\
\mathrm{DO}\end{array}$ & $\begin{array}{l}\text { suru } \\
\text { do }\end{array}$ & $\begin{array}{l}n o . \\
\text { SFP }\end{array}$ \\
\hline
\end{tabular}

2 lines omitted

$\begin{array}{lllll}\text { motto anata } & \text { yoka[yori?] } & \text { yowatteru } & \text { hito ni, } & \text { otasukesuru } \\ \text { more you than } & \text { weaken } & \text { person to } & \text { help }\end{array}$




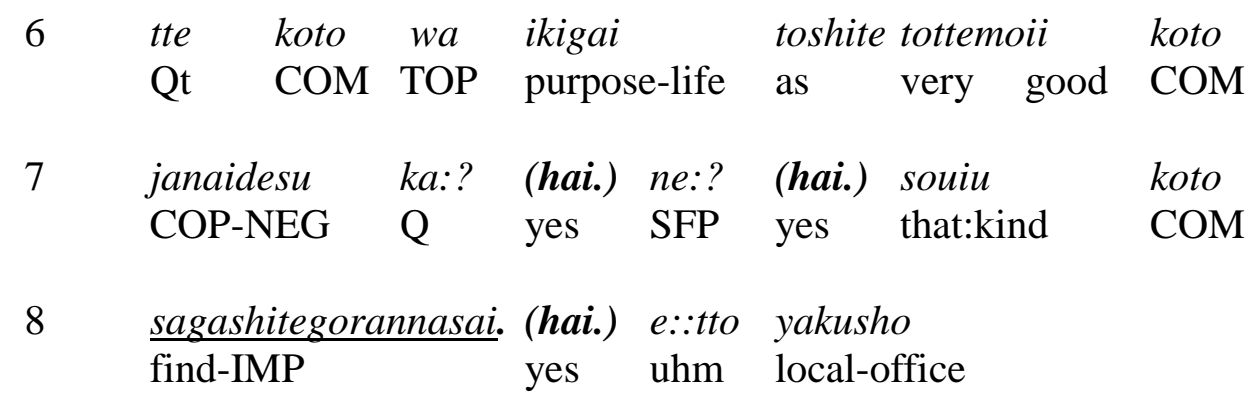

lines omitted

12 boku sou iи shigotoshiterukara. (hai.) ne? (hai.) I that say work do thus yes SFP yes

$\begin{array}{llllll}\text { jojoni yattegorannasai } & \text {.(hai.) } & \text { ne? } & \text { sou } & \text { iu } & \text { toko } \\ \text { slowly do-IMP } & \text { yes } & \text { SFP } & \text { that } & \text { type } & \text { place }\end{array}$

\begin{tabular}{lll} 
ittegorannasai. & (hai.) & ne? (hai.) \\
\hline go-IMP & yes & SFP yes
\end{tabular}

'Ca: I can give you advice because, by chance, I do this type of job.

lines omitted

Wouldn't it be something you can live for if you help others who are in a worse situation than you? (yes) Wouldn't it? (yes) Go and find something like that (yes) uhm the municipal office lines omitted

Because I do this type of work (yes) you see (yes) do it slowly (yes) right? go to those kind of places (yes) ok?(yes)'

From the string of advice in the nasai form (lines 8,13 and 14) it could be said that this is a sequential pattern that is often used in the data. When advising the caller to do some action, the counsellor can enumerate or explain the necessary steps, and these may appear in the imperative form, as above or as in (18).

Given that commands are used infrequently in advice giving and that advisees do not respond positively, we could say that this strategy is not particularly effective in counselling. The nasai are bold on-record FTAs and might be used as a positive politeness strategy to show the advisers' concern and shorten the social distance. However, they may also sound patronizing as they are associated with orders given by a mother or by women in position of power at work (Shibamoto, 1992).

\subsection{Prohibitions}

Prohibitions in Japanese are expressed with the verb in the imperfective form 
accompanied by the words ikenai or dame, which literally mean 'not good'. In comparison to requests, they are perhaps less direct because the prohibition is a general rule whereas the request is more personal. On the other hand, there is a difference between ikenai and dame. Ikenai gives a choice and therefore it implies some moral responsibility (Narrog 2009: 82).

Prohibitions can refer to the speaker's own activity, and whether the action refers to the speaker or the listener can be understood through context. In (5), the problem is about the debts of the caller's brother (presented in examples (1) to (3)), and the advice, which is given in the obligative expression hakkirisasenaito ikenai desu 'it must be made clear', is connected to the previous phrase which mentions a debt. The counsellor says that "first of all", which is emphasized with louder voice and lengthening of the vowel ma:zu, they have to find out how much he owes and to whom. Thus, the action unambiguously refers to that which needs to be taken firstly by the caller, the family or the brother. Note the host's turn in line 4 which helps the caller (and the audience) follow the counsellor's advice -sore hitotsu desune 'that is one thing'. This implies that there are also other things that need to be done. This excerpt comes from the middle stages of the advice-giving process and shows, again, the sequential actions outlined in the counsellor's advice. In lines 6-7, the counsellor says that the whole picture of her brother's debts is unclear, and therefore his first piece of first advice has to take precedence.

(5) $(30.09 .05)$

$1 \mathrm{Co}:$ [Ha:n.] uhm

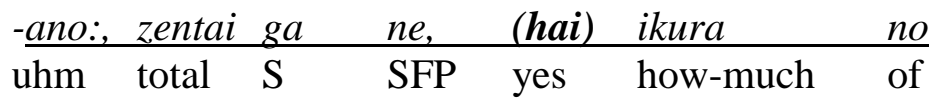

2

\begin{tabular}{|c|c|c|c|c|c|c|c|}
\hline akK & $g a$ & loko & $n i$ & doredake & aru & no & $\mathrm{ka}$ \\
\hline debt & $\mathrm{S}$ & wher & in & how-much & be & $\mathrm{COM}$ & \\
\hline
\end{tabular}

3

\begin{tabular}{lllllll} 
tte & iu & no & o & & MA:ZU hakkirisasenaitoikenai & [desu.] \\
\hline $\mathrm{Qt}$ & say & COM & DO & first & clarify-must & COP
\end{tabular}

$4 \mathrm{H}$ : [un. sore, hitotsu desu ne.] yeah that one COP SFP

5 Ca: [hai] [hai.]

yes yes

6 Co -un.. ima no ohanashi da to: mada uhm now of talk COP Qt yet

7 zenyoo ga wakarimasen.

total $\mathrm{S}$ understand-NEG

'Co: Uhm, well, the total you see? (yes), FIRST you must be clear about the size of the debt and where it is from

$\mathrm{H}$ : [yeah, that is one thing, isn't it?]

$\mathrm{Ca}$ : [yes] [yes] 
Co- uhm, on the basis of conversations to date, you don't know the whole amount.'

Although prohibitions are rather forceful, there is a sense in which they are less strong than commands as they are not directed specifically at the listener. These forms of advice can be very successful in radio programs as they are likely to apply to members of the audience with similar problems. At the same time, the rate of rejection is rather higher than is the case with other types of advice. In the example above, the advisee sends backchannels but does not show resistance, perhaps because it is clear that at this stage the whole advice process has not finished yet, as explained in examples (1)-(3).

\subsection{Requests}

This category includes requests that exhibit hoshii (I want you to do $\mathrm{x}$ ), verbs of giving/receiving kureru/ageru/morau, and verbs in the $\sim$ te form. These requests are considered to be more direct than other forms of advice, except for commands, as the speaker/adviser wants the listener/advisee to do something for the speaker's sake, although the result of the action will be beneficial for the listener (Nitta 1999).

The request with the verb in the conjunctive form followed by the adjective hoshii 'to want' is one of two expressions 'wishing for the realization of an uncontrollable state-of-affairs' (Narrog 2009: 94). Hoshii seems to have a stronger illocutionary force than other advice forms (except for commands and prohibitions) as the speaker wants the listener to do something about which he/she really has no choice. In (6), the counsellor advises the caller to talk to a lawyer (line 1). The caller's problems in this program are related to a dispute over a land corridor connecting her property to the main road. The counsellor's advice is to first consult a lawyer and is given in the structure bengoshi ni mazu soodanshite hoshiindesuyo 'I want you to first consult a lawyer'. Perhaps it is precisely because the counsellor is a lawyer, and knows that talking to someone in his profession is imperative in solving legal problems. The caller sends a backchannel immediately showing an attentive and cooperative stance. Observe that this is just one of many other suggestions given by the counsellor; his use of the word mazu 'first of all' makes it clear that he has more to say. In the subsequent lines, the counsellor goes on to elaborate on what the caller should do.

$(6)(22 \mathrm{a} / 09 / 05)$

\begin{tabular}{|c|c|c|c|c|c|c|}
\hline $1 \mathrm{Co}:$ & $\begin{array}{l}. . \text { ano } \\
\text { well }\end{array}$ & $\begin{array}{l}\text { bengoshi } \\
\text { lawver }\end{array}$ & $\begin{array}{l}n i \\
\text { with }\end{array}$ & $\begin{array}{l}\text { mazu } \\
\text { first }\end{array}$ & $\frac{\text { soodanshitehoshiin }}{\text { counsel-do-want }}$ & $\begin{array}{l}\text { desu } \\
\text { COP }\end{array}$ \\
\hline 2 & $\frac{y o}{\mathrm{SFP}}$ & $\begin{array}{l}\text { (hai) de } \\
\text { yes and }\end{array}$ & $\begin{array}{l}\text { sono } \\
\text { then }\end{array}$ & & $\begin{array}{ll}\text { (hai) } & \text { okareta } \\
\text { yes } & \text { place-PASS }\end{array}$ & $\begin{array}{l}\text { jookyoo } \\
\text { situation }\end{array}$ \\
\hline
\end{tabular}

$\begin{array}{llllll}o & \text { haakushitauede } & \text { (hai) nel } & \text { ima } & \text { kinri ga } \\ \text { DO } & \text { comprehend-after } & \text { yes } & \text { SFP } & \text { now interestS }\end{array}$




$\begin{array}{llll}\text { takai } & \text { kara } & \text { (hai) } & \text { ((continues)) } \\ \text { expensive } & \text { thus yes } & \end{array}$

'Co: ...well, I want you first to talk to a lawyer (yes) and after that (yes) once you understand your situation (yes) you see? because the interest rates are high (yes) (continues)'

While this extract does not contain the whole process of advice giving, it shows that in most cases advice is integrated within the explanation or interpretation of the problem, in particular, when the problem is related to legal matters as we also saw in examples (1)(3) \& (5). Here, the adviser tells the advisee that once she has spoken to a lawyer she would need to take other actions and he elaborates on the steps she has to follow. Although the advice with hoshii has a strong illocutionary force, at the same time it has another dimension as it shows the speaker's concern. While it is the listener who has to act and the action will benefit her or him, the advice is delivered in a manner which suggests that the action is going benefit the speaker; the form 'I want you to do this for me' stresses the speakers' wants.

It has been observed (Tanaka 2014) that legal advice in radio programs is usually devoid of criticism and provides specific and clear steps to be followed and, therefore, the advice is very useful not only for the caller but for the audience and for others who might have a similar problem. One of the pieces of advice that is often repeated regarding legal problems, as mentioned before, is that callers should go to see a lawyer or a professional for help. Counsellors suggest what type information the callers would need to provide and what they need to ascertain from these encounters.

Another form of request is with the verb in the conjunctive form plus auxiliary verbs of giving and receiving such as kureru 'give' or morau 'receive'. The verbs of giving and receiving are based on three criteria. The first one is how the action is viewed (as a giving or receiving action), the second is related to the status of the speaker and the third is the social relationship between the giver and the receiver based on age or social status. Therefore, the verb ageru 'to give' is used when the giver of the action is the speaker or an in-group member, and its form will depend on the status of the receiver. The verb kureru 'to give' and its variations are used for actions that are given towards the speaker and/or in-group members. The verb morau and its variations 'to receive' are used when the receiver of the action is the speaker or an in-group member.

\begin{tabular}{|c|c|c|c|c|}
\hline \multirow{2}{*}{$\begin{array}{l}\text { Receiver's } \\
\text { Status }\end{array}$} & To give & \multirow{2}{*}{$\begin{array}{l}\text { Giver's } \\
\text { status }\end{array}$} & To give & To receive \\
\hline & Verb ageru & & Verb kureru & Verb morau \\
\hline higher & xo shite sashiageru & higher & x o shite kudasaru & xo shite itadaku \\
\hline same & xo shite ageru & similar & x o shite kudasai & xo shite morau \\
\hline lower & x o shite yaru & lower & $x$ o shite choodai & xo shite morau \\
\hline
\end{tabular}

In (7), the caller wants advice for legal issues related to the car ownership of his son who is a minor. As the program evolves it is clear that the caller's son is in more trouble than the father admits. Therefore, the host reproaches him and urges him to be more interested in his own son. The host's criticism also gives advice by inference (lines 1-3) saying that the cause of the problem is the father's apathy. The host also says that it is parents' apathy that turns children into delinquents. The caller's reaction in line 5, which 
is a delayed response, shows that he is unhappy with the host's words and shows resistance to the implied advice. However, when the host gives direct advice in lines 6-8 with moo sukoshi kodomo ni kanshin o motte kudasai 'give more attention to your child', the caller answers immediately saying that he has understood. The verb of giving in the polite form kudasai is the conventional form of requests (Nitta 1999).

(7)(01.09.05)

$1 \mathrm{H}: \quad$ [boku] mo ne:, geni'n wa, do:mo anata no

I also SFP cause TOP DM you of

2

$\begin{array}{llllllll}\text { mukanshin } & n a & n & d a & \text { yo } & \text { ne, } & \text { kodomo } & n i \\ \text { apathy } & \text { COP } & \text { COM } & \text { COP } & \text { SFP } & \text { SFP } & \text { child } & \text { in }\end{array}$

3 taisuru.de mukanshin tte no wa, yapparikodomo towardsand apathy Qt COM TOP after-allchild

4 o, hikoo ni hashirasemasu yo.

DO delinquency to run-CAUS SFP

$5 \mathrm{Ca}: \quad . . h a i$

...yes

$6 \mathrm{H}$ : dakarasoko ga genten da to omoimasu node, thus there $\mathrm{S}$ origin COM Qt thing because

$7 \begin{array}{llllll}\text { (hai) } & \text { moo } & \text { sukoshi } & \text { kodomo } & \text { ni, } & \text { kanshinmottekudasai. } \\ \text { yes } & \text { more } & \text { little } & \text { child } & \text { in } & \text { interest-have-give }\end{array}$

$8 \mathrm{Ca}:$ a. wakarimashita.

oh understand-PAST

' $\mathrm{H}$ : I also (think) that the reason is your indifference to your child. Indifference to one's child makes him/her turn into a delinquent, I assure you.

$\mathrm{Ca}: .$. yes

$\mathrm{H}$ : That is the origin (of the problem), therefore,(yes) please show more interest in your child.

Ca: Oh. I understand.'

It is interesting to compare the reactions of the advisee in the above extract. In line 5, when the adviser accuses him of parental indifference, the advisee's reaction is that of reluctance. Before giving his answer there is a slight pause, which is an indication of his reaction towards the criticism in line 2 . The answer in line 8 to the advice in line 7 is immediate and shows acceptance. This difference in reaction could be due to the implied criticism in the first instance (lines 1-4) and the way in which the second piece of advice is conveyed (line 7). The expression kudasai, as is the case with hoshii, is basically a request on the part of the speaker. In this case, it is still the action of the 
listener that is possibly going to solve the problem; there is not going to be any benefit to the speaker directly, except for professional satisfaction (that the counselling session was successful).

Advice is frequently given in request form, and it tends to occur in the latter stages of the program. The percentage of resistance and subsequent rejection of advice in request form is very low, suggesting that this type of advice is highly effective in radio counselling situations. This might be because the advice is in request form, and as such, it is more difficult to openly reject them.

\subsection{Positive suggestions and conditional suggestions}

Two types of suggestions used to give advice were found in the data: Expressions that use the adjective $i i$ (positive suggestions) and those with the conditional. Positive suggestions can be made using constructions with the adjective $i i$ 'good' and verbs in affirmative past or negative present forms. Thus, the suggestion 'you'd better consult a lawyer' takes the form: bengoshi ni soodanshita hooga ii desu while the negative suggestion 'you'd better not see a lawyer' is: bengoshi ni soodanshinai hoo ga ii desu. The structure of Verb+hoogaii is used in warnings because it implies a "negative evaluation against an alternative state-of-affairs" (Narrog 2009: 87). Moreover, it is a "strategy to avoid expressing obligations directly" (Narrog 2009: 87) therefore it is more commonly used in situations such as counselling. Other types of advice with the adjective $i i$ include the combination of the verb in the conditional such as $i k e b a+i i$ 'it is good if you go' or with the nominalized verb form ikunoga $i i$; however, these were not found in the present data.

As we can see in Table 1, positive suggestions are used frequently, in particular in constructions with hoo ga 'this way'. In (8), the counsellor advises the caller that she should avoid arguing about their inheritance using zettaini 'at all costs' for emphasis. Similar advice, in (9), that the caller should not fight about inheritance with family members, is given in a different format. In this example, the counsellor uses the sentence final particle yo that reflects a strong and forceful stance. In a similar way, the adviser in (10) suggests the caller's brother should move out (in order to sort out his finances) finishing his advice with the particle yo.

$1 \quad \begin{array}{llll}\text { zettaini } & \text { saketa hoo } & \text { ga } & \text { ii, } \\ \text { at-all-costs } & \text { avoid way } & \mathrm{S} & \text { good }\end{array}$

'You should avoid it all costs.'

$1 \begin{array}{lllllll}\sim \text { momanai } & \text { hoo } & \text { ga } & \text { ii } & \text { to } & \text { omou } & \text { yo, } \\ \text { fight-NEG } & \text { way } & \mathrm{S} & \text { good } & \mathrm{Qt} & \text { think } & \text { SFP }\end{array}$

'I think you should not fight, I tell you.'

$\begin{array}{lllllll}1 & \sim \text { utsutta } & \text { hoo } & \text { ga } & \text { ii } & \text { desu } & \text { yo, } \\ \text { move } & \text { way } & \mathrm{S} & \text { good } & \text { COP } & \text { SFP }\end{array}$ 
'He'd better move, I tell you.'

A longer example that includes the response of the caller is shown below. The caller is a woman looking after her sick husband who is in hospital. She complains that she is tired and that her husband takes her for granted. Using the construction hoo ga ii, the host takes over in line 1 suggesting that she should have more rest and do things that she enjoys. The caller answers with the expression aasoodesuka 'is it so' usually used as a backchannel followed by hai and the expression wakarimashita 'I understand' indicating that the caller has accepted the advice. This excerpt is from the later stages of the advice-giving process and the woman had been told to take more time off from going to see her husband in the hospital and relax more. It might be the case that at this stage the caller had been persuaded to do more for herself.

(11) $(16 / 09 / 05)$

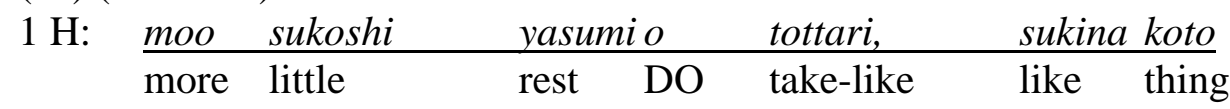

2

\begin{tabular}{llll} 
saretahoogaii & to & omoimasu & yo. \\
\hline do-HON-better & Qt & think & SFP
\end{tabular}

$3 \mathrm{Ca}$ : aa soo desu ka. hai wakarimashita.

oh that COP $\mathrm{Q}$ yes understand-PAST

' $\mathrm{H}$ : I think that you had better do things like take more rest and do things that you like, I mean it.

Ca: Oh, I see. I understand.

Suggestions for advice which contain the adjective $i i$ 'good' can take many endings; however, the main function is to show the listener that the best solution or choice is what the speaker is saying. According to Narrog (2009, expressions of 'strong' obligation are avoided in Japanese, therefore the language has developed various ways in which recommendations are expressed ending in 'a positive evaluation' (Narrog 2009: 85). Although these expressions are much weaker than those with the more forceful 'must' form, they are commonly used in giving advice.

The use of conditionals in advice giving is very common, particularly in the context of everyday talk as it is considered to be a positive politeness strategy. According to Shima (1993), it is one of the advice forms used by lower status persons and therefore contains a certain degree of informality in comparison to other forms. Conditionals are also used to express a wish on the part of the speaker that cannot be fulfilled (Narrog 2009). However, the examples in our data refer to the interlocutor giving a suggestion. In (12), the caller is not happy with the counsellor's advice so the host takes over and offers advice in another format, and only then does the caller shows partial agreement. In line 3, the caller says that she feels the host's interpretation is correct; however, the phrase ends in the conjunctive particle kedomo with a lengthened vowel that reflects an opposing attitude. The host says that he feels relieved (line 5) and continues to tell her that if you accept this interpretation' (of the problem) kore ga atteruto mitometekurereba, then, 'tomorrow will come' asu ga hirakeru. The caller's 
response in line 4 might have been interpreted as acceptance by the host, who says that he feels relieved (line 5). He assures her that if she agrees that this is the reason for her actions (that she lacks self-confidence), then the future will look better.

(12) (31.01.05)

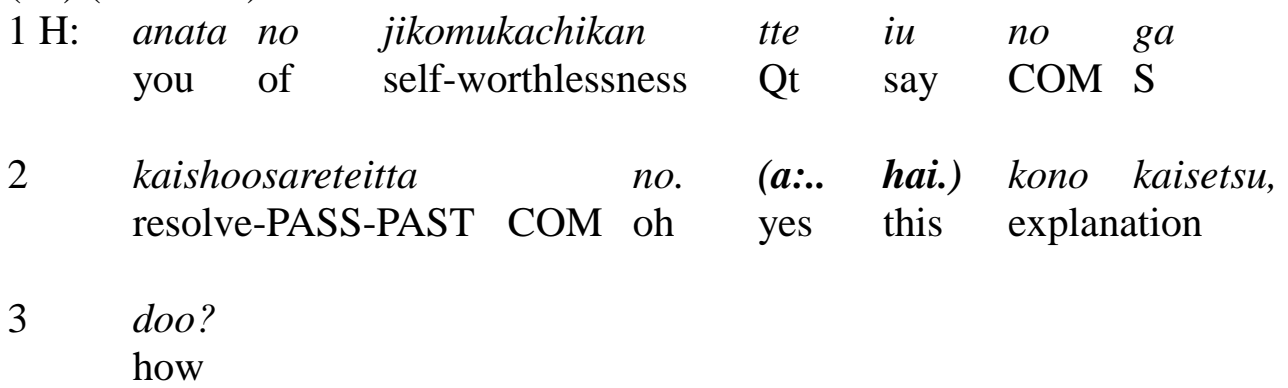

4Ca: atteru yoona kigashimasu kedomo: correct like feel but

$5 \mathrm{H}$ : anone, (hai.) korede anshinshita. kore ga atteru look yes with-this obtain-peace this $\mathrm{S}$ correct

\begin{tabular}{lllll} 
to & mitomete & kurereba, & (hai.)...anata, & asu \\
\hline $\mathrm{Qt}$ & accept & give-COND & yes you tomorrow
\end{tabular}

$\begin{array}{llllll}\text { ga } & \text { hirakeru } & n & \text { desu. } & (\text { a, } & \text { hai. }) \\ \mathrm{S} & \text { open } & \text { COM } & \text { COP } & \text { oh } & \text { yes }\end{array}$

$\mathrm{H}$ : What about seeing it in terms of your feelings of selfworthlessness, having been dealt with (oh, I see) What do you think about this explanation?

Ca: I feel that that is correct, but

$\mathrm{H}$ : Umm, (yes) this could give you some peace of mind. If you accept that this is the case, (yes) you can feel that tomorrow will be brighter.

This section is at the end of the program and in subsequent turns, we can see that the advisee is happy, and the program comes to an end with a resolution. Suggestions offer the advisee the freedom to follow the advice or ignore it. Unlike commands, for example, suggestions are used in a way that gently persuades advisees to follow a course of action. In some instances, such as example (12), a cure for all troubles is promised if the caller follows the counsellor's advice. The fact that there is a choice embedded in the advice might be one of the key issues in accounting for why this format is frequently used. In Table 1 (above), we can see that reactions of resistance are the lowest towards this type of advice. 


\subsection{Asking opinions}

It is interesting that some of the advice is given in question form despite this contradicting the established view of giving advice. However, questions prove to be quite useful in counselling as they take the advisee's opinion into account. Here is one such example. In (13) the caller is a young man who seems very unhappy and undecided about what to do with his life. He is given a number of pieces of advice, which he rejects one after the other. Near the end of the program, the counsellor gives another piece of advice that is a question and contains the tag-like question janai. He asks the caller whether not doing anything (about his life) is a waste. The caller gives an answer accepting or at least agreeing with the counsellor's view. Question forms of advice function also as persuasion strategies.

$\begin{array}{lllllll}1 \mathrm{Co}: & \text { tada } & \text { nanimo } & \text { shinai } \\ \text { only } & \text { nothing } & \text { hoo } & \text { ga } & \text { mudajanai?, } \\ \text { way } & \text { S } & & & & \\ \text { waste-NEG } & \text { soo } & \text { desu ne } & & & & \\ & \text { yes } & \text { COP FP } & & & & \end{array}$

'Co: Not doing anything is a waste, isn't it?

Ca: Well, yes you are right.'

Asking opinions to obtain an outcome, in this case to solve a problem, seems to be a very consensus-conscious strategy that might be particular to these programs or to Japanese in general. However, it is too early to make any generalizations; it may, perhaps, be one strategy taken when all else fails as in the case of the program above.

\subsection{Assertion of opinion}

The majority of advice in the data is expressed as assertions of opinions. Assertions of opinions are constatives or speech acts that are used to transmit information (Bach and Harnish 1979; Geis 1995; Kissine 2013). When used to give advice, these statements show either the speaker's personal opinion or facts such as in examples (14)-(16). In (14), the counsellor strongly suggests that the caller obtain her brother's financial details and then go to a lawyer. The advice is similar in (15) where the adviser says that what has been suggested (to the caller) has to be carried out. In these two statements the expressions hitsuyoo ga aru 'there is a need to' and shinakya shooganai 'you cannot avoid but doing ' convey the urgency and the necessity to do what the adviser suggests. Contrary to advice in conditional forms, where the advisees are left with a choice, these assertions seem to have a stronger illocutionary force although sometimes they can be stated in ways that sounds less assertive, as in (16), where the suggestion is that there might be other ways of solving the problem. The use of question particles and SFPs projects a softening of the statement, and they can function as hedging devices (Nitta, 1999). 
(14)

1 hakkiri tokuteishita uede gosoodannasaru hitsuyoo ga aru to clear specify-PAST after consult-HON need $\mathrm{S}$ be Qt

2 omou no ne,

think COM SFP

'I think that there is a need to consult (a lawyer) after everything has been clarified.'

(15)

1 kore shinakya shooganai desu yo,

this do-must no-way COP SFP

'This (is something) that you cannot avoid doing, you see.'

(16)

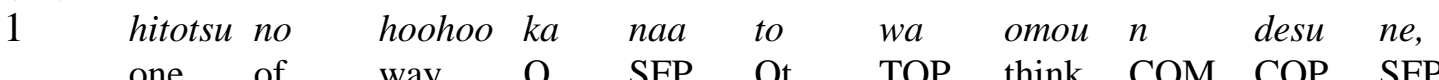

'I think that (what I am suggesting) might be one way of (resolving the matter).'

In other statements, the use of the specific word ichiban 'the best' emphasizes that the action suggested by the counsellor is paramount. The caller in (17) says that she has called because she suffers from depression, but it gradually emerges that she also has other problems. She explains that she regrets not getting proper treatment the first time she was diagnosed with depression and blames that inaction for her present state. In lines 1-2, the counsellor tells her that regretting will lead her nowhere:kookai shitemo shooganai 'it cannot be helped by regretting'. He says that what she needs now is to get the best treatment 'ima dekiru kagiri no chiryoo ukeru koto'. Note the use of the word ichiban which literally means 'number one' and also the predicate which emphasizes that his suggestion is the best action she can take. The advice of the counsellor is endorsed by the host who joins the discussion in line 4. The caller's response in this example is that of acceptance. It is difficult to know if the acceptance is due to the type of advice or because of its timing. This section comes after a number of turns where the counsellor and the host had offered much support and sympathy. Therefore, it can be hypothesized that the caller felt she had been heard and understood, a feature discussed by Abe (2006).

(17) (22.09.05)

$\begin{array}{rllll}1 \text { Co: maa demo } & \text { kookaishitemo shooganaishi } & \text { ne, } & \text { (hai) } \frac{\text { dakara }}{\text { well but }} \\ & \text { regret-even cannot-be-helped } & \text { SFP yes }\end{array}$

2 \begin{tabular}{lllll} 
ima dekiru kagiri & no & chiryoo & ukeru koto & ga \\
\hline now do-POT limit of & treatment & receiveCOM & $\mathrm{S}$
\end{tabular} 


$\begin{array}{ll}\text { Lichiban } & \text { deshoonel } \\ \text { best COP } & \text { SFP }\end{array}$

$4 \mathrm{H}: \quad[x x]$ naniwatomoarebyookio
at-any-rate illness DO fix Qt

$5 \mathrm{Ca}$ : hai

yes

$6 \mathrm{Co}: n: \quad$ soo $\quad d a \quad n e:$.

$\mathrm{mm}$ yes COP SPF

7 Ca: hai.

yes

'Co: Well, but regretting will lead you nowhere, will it? (yes)That's why now the best thing is for you to get the[ best treatment]

$\mathrm{H}:[\mathrm{xx}]$ at any rate, (it means) that you get well

Ca: yes

Co: Mmm, yes, that's it.

Ca: Yes.'

The fact that statements are frequently used in the process of advice giving seems to be unrelated to the success or failure of the consultation as they appear in different stages of the exchange and the advisee's reaction is also varied. However, it is interesting to note that they comprise a vast majority of advice in the data. Although some exhibit hedging, statements in a sense have a stronger illocutionary force as they are expressed as personal opinions or facts (that cannot be refuted); hence statements might be a more effective way to provide advice.

\subsection{Assertion of instructions}

Another group of advice that did not fall into one neat category included instances of the adviser telling the caller what to say. In other words, advice that contains instructions on what the advisee should tell someone else in order to solve the problem. In the next example, the caller is a man who found that his wife was cheating on him and confronted both the lover and the wife. At this point, the caller is quite determined to get a divorce, but wants advice in relation to how he can proceed to sue the other man. $\mathrm{He}$ is given legal advice before this excerpt concerning how much he can demand for compensation. In this excerpt, the counsellor tells him that as a man, he has to tell his wife's lover to take responsibility. Although the counsellor does not use the words 'tell him' in lines 4 and 5, the fact that the phrases in lines 5, 8, 9 and 10 are accompanied by the quotative particle enables us to deduce that these are quotations. The second 
'quotation' says that because he was so angry yesterday it had not been possible to have any dialogue, but that now they should talk anew face to face sashide hanasoo yanaikato. Then he continues in lines 8 and 9 with the question doregurai dattara omae haraerun da to 'How much can you pay?' and the final section includes the phrase oriaitsukeyoo to 'let's come to a compromise'.

(18)

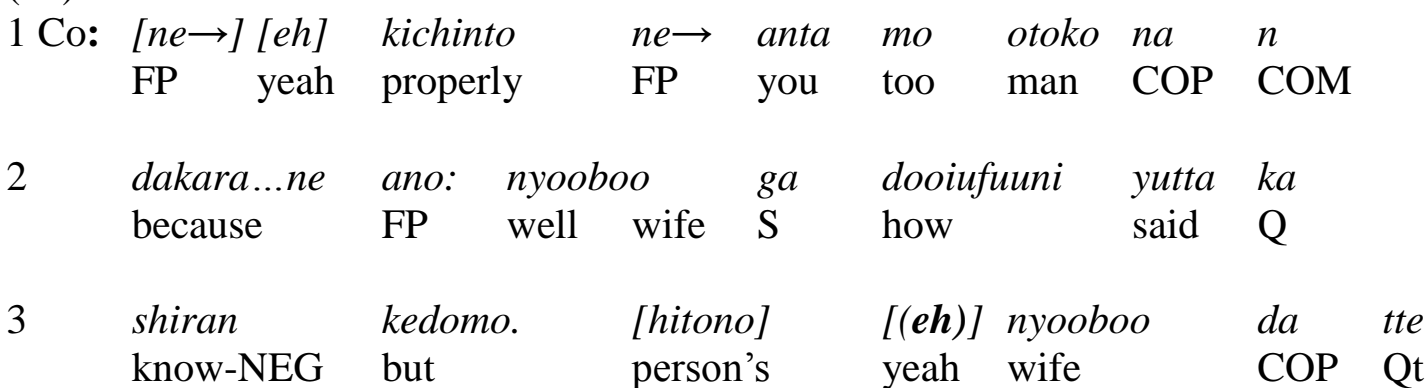

4 iu koto wa wakatteta $n$ dakara. kejimeguraiwatsukenasai say COM TOP know-PAST COM because take:responsibility-IMP

$\begin{array}{llllll}\text { yo } & \text { to } & & (\text { H:un })[n e ? \uparrow][(\boldsymbol{e h})] \text { maa. } & \text { kinoo } & \text { wa } \\ \text { FP } & \text { Qt } & \text { yeah FP yeah well yesterday } & \text { TOP }\end{array}$

$\begin{array}{lllllll}\text { gyakujooshite } & \text { yutta } & \text { kara } & \text { saa. } & \text { [are dakedo] } & \text { [ @@@] } \\ \text { Enraged } & \text { say:PAST } & \text { because } & \text { FP } & \text { uhm but } & \end{array}$

\begin{tabular}{llllll}
{$[(\boldsymbol{e h})]$} & saa. & aratamete & ne? & sashide & hanasoo \\
\cline { 2 - 5 } yeah & FP & anew & FP & face-to-face & talk-HORT
\end{tabular}

$\begin{array}{lllllll}\text { yanai } & k a & \text { to. } & \text { de } & \text { doregurai: } & \text { dattara } & \text { omae } \\ \text { COP-NEG } & \mathrm{Q} & \mathrm{Qt} & \text { and } & \text { how:much } & \text { be-COND } & \text { you }\end{array}$

$\begin{array}{lllllll}\text { haraeru } & n & d a & \text { to. } & \text { moo } & {[\text { sorede] }} & {[(\text { hai })]} \\ \text { pay-COND } & \text { COM } & \text { COP } & \text { Qt } & \text { well then } & \text { yes }\end{array}$

10 oriaitsukeyoo to (eh)

compromise-HORT Qt yeah

'Co: See (yes), because you are a man, and I don't know what or how your wife told you, but because he knew that it was somebody's [wife] [(yes)] that's why, \{you have to tell him $\}$ take responsibility [you see?] [well. yesterday I was mad with anger [but you see ] [ H: @@ Ca: (yea:h)] \{tell him\}let's talk face to face. How much can you pay? [And] [(yes)] Let's use that as a starting point for coming to a compromise \{tell him\} (yeah). 
This section shows the counselor suggestions of possible dialogues that the caller can use to talk to his wife's lover. It is clear that the caller does not resist the advice and that his responses are backchannels. The indirectness of the advice makes it more mitigated than a command and this might be why it proves to be very effective.

\section{Discussion}

This paper has shown that advice giving needs to be seen as a 'process'. Through an indepth analysis of excerpts, we saw that advice is embedded within explanations, interpretations of the problem and the opinions of the advisor. The advice usually follows a sequence of steps that the advisee should follow in order to obtain a solution. Most of the advice does not come as an independent 'unit' - as observed in the various examples - but seems to be a part of a 'package' of several intertwined suggestions that can be given by counsellors or by hosts, in particular for legal problems. This aspect is closely related to the complexity of the problems that most callers have (DeCapua and Dunham 1993). Many of these involve relationships and also legal issues, making it necessary for the counsellors to give advice and explain why and how the callers have to act on particular suggestions. DeCapua and Dunham (1993) also stress this aspect of advice giving, explaining that in many cases this 'process' is complex and that after having helped to clarify an individual advisee's problem, advisers offer broader, 'global', advice to the audience. In addition, many callers do not immediately reveal the extent of their problems, and this might be one of the reasons why different types of advice have to be given at each different revelation within one counselling session. As mentioned earlier, some of the problems are just symptoms of a bigger, more complex problem, thus, different types of advice are needed to address each issue. At other times, callers simply cannot explain their tribulations in a concise way (examples (5) and (13)), or the problems are too complex especially when they have a long history (examples (4), (14), (15)). In some cases, counsellors start discovering other issues as they begin to diagnose the cause of the original problem (examples (6) and (18)). The complexity of the 'problem' is sometimes made more difficult to unravel when the callers themselves are not aware of the real cause (example (18)). This is usually 'discovered' by the counsellor after much probing. In these cases, callers can come to see their problems in a different light and this can lead to a resolution in the end.

I have also focused on the formal characteristics of advice in radio phone-in counselling and found that counsellors and hosts use a varied array of speech acts to convey advice. These were categorized according to their degree of directness. The most direct form of advice is when advisers use orders or commands as these are considered to be bold, on record FTAs, and the most forceful form of advice. However, as mentioned previously, these commands are in the nasai form used mainly by mothers when disciplining their children or when female superiors give orders to their employees. Next, in order of directness, were prohibitions in structures with dame and ikenai that, although not as strong as imperatives, are forceful because they can imply moral responsibility (e.g. ikenai: see Narrog 2009). Requests with various combinations with the verbs of giving and receiving seem to be the most strategic way of advising as they ask the advisees to do something for the speaker. Suggestions with $i i$ and in the conditional forms are also used as advice. These forms are polite and the advisee has the 
freedom to follow or ignore the suggestion. Suggestions in the conditional form, the syntactic form most commonly associated with advice (Nitta 1999), are used often and considered to be positive politeness strategies as seen in the studies of Murakami (1994) and Shima (1993). Then, there are instances of advisors asking for opinions as a means of giving advice. Because of their consultative stance, opinions are successful advicegiving forms and the advisees do not reject them often. The most common types of advice are in the form of assertions of opinions and they are distributed evenly throughout the advice-giving phase of a program. Lastly, there are assertions of instructions in which the advisors instruct the advisee as to what they should tell other people. The variety of advice forms in the data might be a characteristic of counselling interactions because of two factors: The complexity of problems and the callers' need for considerable persuasion. This raises an interesting question regarding whether the features noted in this paper result from the interaction being a radio program where the length of the consultation must fit the allocated time or whether this is a general feature of counselling exchanges.

The fact that counsellors and hosts use assertion of opinions as advice more often than any other types of advice is interesting. Statements are the experts' opinions and therefore might be highly effective in delivering advice without being forceful because advisees understand that in the context of the counselling session, opinions (and instructions) given by the counsellor should be interpreted as advice (Searle 1975). Known also as constatives, they "express the speaker's belief and his intention or desire that the hearer have or form a like belief" (Bach and Harnish 1979: 41). These constatives can be interpreted as advice not only because of the context but also due to our ability to understand how something is said (Haviland 1989). Similarly, requests and suggestions have been reported by other scholars as default advice forms (Hoshino 2005; Nitta 1999; Shima 1993), and they are frequently used in the present data as well. Even though the status difference in this data is quite defined, suggestions used to give advice are frequent enough to challenge Shima's findings. She reports that lower status speakers use suggestions towards higher status listeners. In the present data, it is clear that the counsellor has a higher status than the advisees, yet these types of advice are used often. This suggests that the crucial factor might be that the listener is free to choose whether or not to follow the action suggested, in particular when the conditional forms $\sim$ tara/ba are used. The fact that they are mere suggestions might be a more important variable rather than the status of the interlocutors.

In the numerical analysis, it is worthy of note that the percentage of rejections of commands and prohibitions is greater or at least equal to that of acceptance. Commands, in particular, show the highest discrepancy amongst all forms of advice in percentage of rejections compared to acceptance ( $27 \%$ vs $9.1 \%)$. On the other hand, the percentage of acceptance of requests, suggestions and asking opinions is relatively high $(64 \%, 50 \%$, $72 \%, 64 \%)$. The response to assertions, however, does not show any particular trend ( $15 \%$ vs $22 \%, 33 \%$ vs $33 \%$ ). These figures indicate that advisees might react negatively to strong and direct forms of advice and show a more accepting response to those in request or suggestion form. However, it might also be the case that advice given in the latter stages of a consultation is more readily accepted. Commands are mostly given in the early stages of the process whereas requests, suggestions and questions are given in the last phase. Therefore, the fact that advisees accept advice more readily when given in request, suggestion or question form might be because it is given after callers have 
had the opportunity to feel listened to. Advisees might more readily accept advice once they feel their grievances have been heard by the counsellor, and it may be that it is this process in the counselling, rather than the type of advice that is a determining factor. Gaik (1992) and DeCapua and Dunham (1993) write about the difference between therapy and counselling. One of the goals in therapeutic encounters is for callers 'to discover or explore the unique reasons of their anxiety' (Gaik 1992: 284) whereas counselling has a different objective. Similarly, in a cross-cultural study on advice in America and Japan, Abe (2006) writes that Japanese advisees are quite happy to be listened to rather than needing concrete advice. It seems that in the present data something similar is occurring. The callers seem to feel satisfied when they have been listened to and, therefore, are more ready to accept advice given in the final stages of the interaction.

As mentioned before, each piece of data must be seen as pertaining to a particular speech event. In other activity types such as service encounters, for example, the advice can be short, succinct and direct, and usually problems have easy solutions (Jefferson and Lee 1992). However, in radio phone-in programs and other counselling exchanges, the purpose is to give callers an opportunity to 'air their grievances' and receive some useful advice (this also applies to the overhearing audience) or to get reassurance. It is important to remember that Abe (2006) writes of the tendency among Japanese advisees to feel quite happy to be listened to and of the fact that they are not after concrete advice when they call these services. As DeCapua and Dunham (1993) state, advisers' roles in these interactions are to help advisees understand their problems and to provide advice. Moreover, advisees, in some cases, have already made a decision but need reassurance that can be provided by the advisers (Heritage 1985).

Naturally, we cannot ignore the importance of 'face' in situations where advice is given and received. As mentioned earlier, advice represents a potential FTA and if it is given as a command, particularly if given bold on-record in a situation that is not an emergency (Brown and Levinson 1987), the degree of face-attack increases. The advisee's reaction to save face would most probably result either in resistance or open rejection. On the other hand, requests or suggestions are less imposing and give the advisee the freedom to choose whether to do the action or not. Therefore, and this might be crucial in understanding the high number of assertions of opinion as advice, advisees have a choice. Allowing room for choice shows that advisees are considered to be competent and independent enough to make the 'right' decision. The fact that assertions are delivered as the 'expert's' opinions means that they are not FTAs, and this might be one of the reasons why they are so frequently used. When an adviser gives an advice as the expert's opinion, this opinion is likely to be interpreted by the caller as the solution to a problem. After all, they have been invited to participate in the program because of their expertise. And these assertions, although they can be interpreted as advice because of the context (Kissine 2013) do not enforce any action and can function as 'global advice' (Bach and Harnish 1979).

The findings of this study are particular to the speech events that have been examined, and might not be found in other types of counselling, for example private counselling. We should not forget that one of the purposes of these programs is to broadcast for a broad audience, and as programs offered by a media provider there are a number of factors that have to be considered. One of these is the issue of time restrictions. Programs last 20 minutes and the producers have to select interactions that 
will fit this format. This pre-broadcast selection process might mean that there were other interactions that were resolved more quickly or that were not successful and thus not broadcast. Topic is another critically important factor. Although this is beyond the scope of the present study, in media broadcasting there is an element of entertainment which undoubtedly influences the choice of interactions to be aired. Thus, the critical attitude of the adviser, for example, can be a characteristic of these speech events (Culpeper 2005; Tanaka 2014).

One of the difficulties in this study is the lack of possibility for verifying advisees' reactions. The only means used to judge acceptance or resistance has been the close and detailed analysis of conversational cues found in the exchange. Future research could include the advisees' and advisers' impressions of the interaction. Similarly, other types of counselling encounters should be explored to see if advice is delivered and received in a similar fashion. Further research could also be applied to other languages and cultures to increase our understanding of how advice is given and how it is perceived.

\section{Conclusion}

This study has focused on the formal characteristics of advice in Japanese radio phonein programs. We have seen that advice-giving is a 'process' where advice is given through various speech acts such as commands, assertion of opinions, requests or suggestions that are embedded within explanations and persuasion. One of the major points to emerge has been the difficulty of stating whether the critical determinant in advice being accepted more readily is the indirect manner in which it is given or its occurrence in the latter stages of the interaction. These observations suggest that the correlation between the advice's characteristics and acceptance or rejection might be small, and that advisees are more ready to accept advice after the adviser has spent some 'amount' of time on persuasion; the readiness to accept advice would then be related to the counselling and/or therapeutic process in the exchange. The need for advisees to feel reassurance and that they have been listened to indicate that in advice-giving processes timing is a crucial factor. Similarly, advice given indirectly as the opinion of the 'expert' appears to carry more weight and be more readily accepted than other forms of advice

\section{References}

Abe, Keiko (2006) 'How may I help you?' Advice by radio in Japan and the U.S.. In A. M. Hornero Corsico, M.J. Luzón, and S. Murillo Ornat (eds.), Corpus Linguistics: Applications for The Study of English. Bern: Peter Lang, pp. 79-92.

Altman, Roann (1990) Giving and taking advice without offence. In R. Scarcella, E. Andersen, and S. Krashen (eds.), Developing Communicative Competence in a Second Language. New York: Newbury House, pp. 95-101. 
Press.

Blum-Kulka, Shoshana (1987) Indirectness and politeness in requests: Same or different? Journal of Pragmatics 11.2: 131-146.

Brown, Penelope, and Steven Levinson (1987) Politeness: Some Universals in Language Usage. Cambridge: Cambridge University Press.

Culpeper, Jonathan (2005) Impoliteness and entertainment in the television quiz show: The Weakest Link. Journal of Politeness Research 1: 35-72.

Culpeper, Jonathan (2011) Impoliteness: Using Language to Cause Offence. Cambridge: Cambridge University Press.

Culpeper, Jonathan, Robert Crawshaw, and Julia Harrison (2008) 'Activity types' and 'discourse types': Mediating 'advice' in interactions between foreign language assistants and their supervisors in schools in France and England. Multilingua 27: 297-324.

DeCapua, Andrea, and Joan F. Dunham (1993) Strategies in the discourse of advice. Journal of Pragmatics 20.6: 519-539.

Gaik, Frank (1992) Radio show therapy and the pragmatics of possible worlds. In A. Duranti, and C. Goodwin (eds.), Rethinking Context: Language as an Interactive Phenomenon. Cambridge: Cambridge University Press, pp. 271-290.

Geis, Michael (1995) Speech Acts and Conversational Interaction. Cambridge: Cambridge University Press.

Goldsmith, Daena J. (1992) Managing conflicting goals in supportive interaction: An integrative theoretical framework. Communication Research 19: 264-286.

Goldsmith, Daena J. (1994) The role of face work in supportive communication. In B.R. Burleson, T.L. Albrecht, and I. Sarason (eds.), The Communication of Support: Messages, Interactions, Relationships, and Community. Newbury Park, CA: Sage, pp. 29-49.

Goldsmith, Daena J. (1999) Content-based resource for giving face sensitive advice in troubles talk episodes. Research on Language and Social Interaction 32.4: 303-336.

Goldsmith, Daena J. (2000) Soliciting advice: The role of sequential placement in mitigating face threat. Communication Monographs 67: 1-19.

Grice, Paul (1978) Logic and conversation. In P. Cole, and J. Morgan (eds.), Syntax and Semantics 9: Pragmatics. New York: Academic Press, pp. 41-58.

Have, Paul ten (1993) Talk and institution: A reconsideration of the "asymmetry" of doctor-patient interaction. In D. Boden, and D. Zimmerman (eds.), Talk and Social Structure. Cambridge: Polity Press, pp. 138-163.

Have, Paul ten (1999) Doing Conversation Analysis: A Practical Guide. London: Sage.

Haviland, John (1989) Sure, sure: Evidence and affect. Text 9.1: 27-68.

Hayashi, Makoto (2003) Joint Utterance Construction in Japanese Conversation. Amsterdam: John Benjamins Publishing Company.

Heritage, John, and Paul Drew (1992) Talk at Work. Cambridge: Cambridge University Press. 


\section{Lidia Tanaka}

Heritage, John, and Sue Sefi (1992) Dilemmas of advice: Aspects of the delivery and reception of advice in interactions between health visitors and first-time mothers. In P. Drew, and J. Heritage (eds.), Talk at Work. Cambridge: Cambridge University Press, pp. 359-417.

Heritage, John (1985) Analyzing news interviews: Aspects of the production of talk for an overhearing audience. In T.A. van Dijk (ed.), Discourse and Dialogue. London: Academic Press, pp. 95-117.

Hinkel, Eli (1994) Appropriateness of advice as L2 solidarity strategy. RELC Journal 25.2: 71-93.

Hinkel, Eli (1997) Appropriateness of advice: DCT and multiple choice data. Applied Linguistics 18.1: 126.

Horiguchi, Junko (1997) Japanese Conversation by Learners and Native Speakers. Tokyo: Kuroshio.

Hoshino, Yuko (2005) Positive politeness in Japanese advice giving. Ningen Bunka Rongyo 8: 317-326.

Hudson, Thom (1990) The discourse of advice giving in English: I wouldn't feed till spring no matter what you do. Language and Communication 10.4: 285-297.

Hutchby, Ian (1995) Aspects of recipient design in expert advice-giving on call-in radio. Discourse Processes 19.2: 219-38.

Jefferson, Gail, and John R.E. Lee (1992) The rejection of advice: managing the problematic convergence of a "troubles' teller" and a "service encounter". In P. Drew, and J. Heritage (eds.), Talk at Work. Cambridge: Cambridge University Press, pp. 521-548.

Kissine, Mikhail (2013) Form Utterances to Speech Acts. Cambridge: Cambridge University Press.

Leech, Geoffrey (1983) Principles of Pragmatics. London: Longman.

Leppänen, Vesa (1998) The straightforwardness of advice: Advice-giving in interactions between Swedish district nurses and patients. Research on Language and Social Interaction 31.2: 209-239.

Levinson, Stephen (1992) Activity types and language. In P. Drew, and J. Heritage (eds.), Talk at Work: Interaction in Institutional Settings. Cambridge: Cambridge University Press, pp. 66-100.

Locher, Miriam (2006) Advice Online. Advice-giving in an American Internet Health Column. Amsterdam: John Benjamins Publishing Company.

Murakami, Megumi (1994) Resistance to advice and negotiation process: A case study of radio-advising sessions. Bulletin of the Faculty of Education, Hiroshima University 43: 327-338.

Murakami, Megumi (1995) Persuasion behavior in radio-advising sessions. Bulletin of the Faculty of Education, Hiroshima University 2: 219-229.

Nakamura, Kazuo, and Yoshio Kashida (2004) Jogensha-soodansha toiu shoochi. Shakaigaku Hyooron 55.2: 80-97.

Narrog, Heiko (2009) Modality in Japanese: The Layered Structure of the Clause and Hierarchies of Functional Categories. Amsterdam: John Benjamins Publishing Company.

Nitta, Yoshio (1999) Nihongo no Modaritii to Ninshoo. Tokyo: Hitsuji Shobo.

Sacks, Harvey (1986) On the analyzability of stories by children. In J. Gumperz, and D. Hymes (eds.), Directions in Sociolinguistics: The Ethnography of Communication. Oxford: Basil Blackwell, pp. 325245. (Original work published 1972). 
Searle, John (1975). Indirect speech acts. In P. Cole, and J. Morgan (eds.), Syntax and Semantics. Vol. III: Speech Acts. New York: Academic Press, pp. 59-82.

Shibamoto, Janet (1992) Women in charge: Politeness and directives in the speech of Japanese women. Language in Society 21.1: 59-82.

Shima, Hiroko (1993) Joshi no hyoogen 'taradoodesuka' 'sureba?' o megutte: poraitonesu no kanten kara. Kanazawa University Journal of Education Center for Foreign Students 2: 13-23.

Suzuki, Kyoko (2002) Rajio no iryo soodan no danwa no koozoobunseki. Waseda University Japanese Education Department Bulletin 1: 117-130.

Suzuki, Kyoko (2003) Rajio no shinri soodan no danwa no koozo bunseki. Waseda University Japanese Education Department Bulletin 3: 57-69.

Suzuki, Kyoko (2007) Kinoobunkei ni motozuku danwa no koozoo bunseki. Unpublished Ph.D. Thesis. Waseda University.

Szatrowski, Polly (1994) Nihongo no Danwa no Koozoo Bunseki. Tokyo: Kuroshio Shuppan.

Tanaka, Lidia (2004) Language, Gender and Culture. Amsterdam: John Benjamins Publishing Company.

Tanaka, Lidia (2006) Turn-taking in Japanese Television Interviews: A Study on Interviewers' Strategies. Pragmatics 16.2/3: 361-398.

Tanaka, Lidia (2014) Impoliteness in Japanese: Delivery and reception of FTAs in Japanese Radio Phonein programs. Unpublished manuscript.

Terkourafi, Marina (2011) The puzzle of indirect speech. Journal of Pragmatics 43: 2861-2865.

LIDIA TANAKA is Senior Lecturer in the Japanese Program at La Trobe University. She published a book titled Gender, language and culture (2004) on the factors of age and gender in Japanese television interviews and more recently Japanese Questions: Discourse, Context and Language (2015). Her research interests are in Japanese interaction, gender and language, institutional language.

Address: Asian Studies, School of Social Sciences, La Trobe University, Bundoora, 3086, Victoria, Australia. E-mail: 1.tanaka@latrobe.edu.au 